\title{
NK Cells and Their Ability to Modulate T Cells during Virus Infections
}

\author{
Kevin D. Cook, ${ }^{1}$ Stephen N. Waggoner ${ }^{2}$ \& Jason K. Whitmire ${ }^{1,3, *}$ \\ ${ }^{1}$ Department of Genetics, UNC-Chapel Hill School of Medicine, Chapel Hill, North Carolina 27599-7264, USA; ${ }^{2}$ Center \\ for Autoimmune Genomics and Etiology, Department of Pediatrics, Cincinnati Children's Hospital Medical Center and \\ University of Cincinnati College of Medicine, Cincinnati, Ohio 45229, USA; ${ }^{3}$ Department of Microbiology \& Immunology, \\ UNC-Chapel Hill School of Medicine, Chapel Hill, North Carolina 27599-7264, USA
}

*Address all correspondence to: Jason K. Whitmire; 5062 Genetic Medicine Research Building, 120 Mason Farm Road, Chapel Hill, NC 27599-7264; Phone: 919-843-7081; FAX: 919-843-4682; E-mail: jwhitmir@email.unc.edu

\begin{abstract}
Natural killer (NK) cells are important in protection against virus infections, and many viruses have evolved mechanisms to thwart NK cell activity. NK cells respond to inflammatory signals at an early stage of virus infection, resulting in proliferation, cytokine production, and cytolytic activity that can reduce virus loads. Moreover, the rapid kinetics of the NK cell response enables NK cells to influence other populations of innate immune cells, affect the inflammatory milieu, and guide adaptive immune responses to infection. Early NK cell interactions with other leukocytes can have long-lasting effects on the number and quality of memory $\mathrm{T}$ cells, as well as impact the exhaustion of $\mathrm{T}$ cells during chronic infections. The ability of NK cells to modulate $\mathrm{T}$ cell responses can be mediated through direct T-NK interactions, cytokine production, or indirectly through dendritic cells and other cell types. Herein, we summarize our current understanding of how NK cells interact with T cells, dendritic cells, B cells, and other cell types involved in adaptive immune responses to virus infection. We outline several mechanisms by which NK cells enhance or suppress adaptive immune response and long-lived immunological memory.
\end{abstract}

KEY WORDS: innate immunity, adaptive immunity, T cell memory, cytokines

ABBREVIATIONS: Bat3: HLA-B-associated transcript-3; CD: cluster of differentiation; DC: dendritic cell; DNAM-1: DNAX accessory molecule-1; Ly: lymphocyte antigen; HA: hemagglutinin; HBV: hepatitis B virus; HCV: hepatitis C virus; HIV: human immunodeficiency virus; HLA: human leukocyte antigen; IFN: interferon; IL: interleukin; IL-2R: interleukin-2 receptor; IL-15R: interleukin-15 receptor; KIR: Killer-cell immunoglobulin-like receptors; KLRG1: killer cell lectin-like receptor subfamily G member; LCMV: lymphocytic choriomeningitis virus; MCMV: mouse cytomegalovirus; NA: neuraminidase; NK: natural killer; PD-1: programmed cell death protein-1; STAT: signal transducer and activator of transcription; $\mathbf{T}_{\mathbf{F H}}$ : T follicular helper cell; TGF $\beta$ : transforming growth factor beta; Th1: T helper cell 1; TRAIL: TNF-related apoptosis-inducing ligand; TRAIL-R: TRAIL-receptor

\section{INTRODUCTION}

Natural killer cells play an important role in immune defense against virus infections and cancer through their cytolytic activity and production of cytokines. ${ }^{1-4}$ NK cells can respond to inflammation and recognize molecular cues on certain target cells, thereby facilitating the production of IFN- $\gamma$ or the direct cytolysis of those target cells to suppress virus replication. ${ }^{5}$ Targets of NK cell cytolysis, including infected cells, are usually distinguished by reduced expression of $\mathrm{MHC}$-related ligands for NK cell inhibitory receptors and elevated expression of pathogen-derived or stress-activated host ligands for NK cell activating receptors. ${ }^{6}$ Infected cells can also be recognized and lysed indirectly by NK cells through a phenomenon termed antibody dependent cellular cytotoxicity (ADCC), wherein antigens on the target cells are bound by virus-specific antibodies that subsequently engage $\mathrm{Fc}$ receptors on the NK cell. In addition to direct control of virus replication, NK cells have been implicated in modulating other aspects of the host antiviral response.

NK cells are typically identified by their surface expression of NK1.1 and NKp46 (in mice) or CD56 
(in humans). However, there are numerous molecules that are expressed on NK cells that influence their functions and can be used to follow their activation state after infection. NK cells develop in the bone marrow and seed the peripheral compartments, which include the blood, secondary lymphoid organs, nonlymphoid organs, thymus, and mucosal sites. ${ }^{7-9}$ In the homeostatic state, NK cells are abundant ( $5 \%$ of splenocytes in mouse; $5 \%-20 \%$ of peripheral blood leukocytes in healthy people), and they are capable of proliferating under inflammatory conditions. Mature NK cells are heterogeneous in terms of surface receptor expression in mice and in humans. ${ }^{7,10,11}$ Part of this variation is due to genetic and epigenetic variation in germline-encoded activating and inhibitory receptor expression. Other variation is due to environmental influences, such as recent infection. A recent analysis of human NK cell diversity in the peripheral blood used mass cytometry, or cytometry by time of flight (CyTOF), to simultaneously survey 28 NK cell receptors in different individuals. ${ }^{11}$ That study showed that there are 6000-30,000 phenotypic populations of NK cells within an individual and $>100,000$ phenotypes across individuals. Based on a comparative analysis of NK cells in monozygotic twins compared to unrelated donors, it was concluded that inhibitory receptor expression was primarily driven by genetics whereas environmental factors regulate activation receptor expression. ${ }^{11}$ These differences likely contribute to functional heterogeneity among NK cells in mice and man. ${ }^{10}$ For example, tissue resident NK cells differ phenotypically — and probably differ functionally - from NK cells in lymphoid organs or in circulation. ${ }^{12}$ This variation likely affects immune defense. NK cells in mucosal sites are a first line of defense against infections and are also involved in recruiting other cell types to those sites of infection. ${ }^{13-15}$ It is plausible that NK cells residing in each tissue have dedicated functions involved in limiting infection, inducing protective immune responses, dampening potentially harmful immune responses, or tissue repair.

Historically, NK cells have been regarded as integral components of immune-mediated elimination of infected, damaged, or transformed cells. Soon after NK cells were discovered, ${ }^{16,17}$ it became apparent that NK cells are activated as a consequence of virus infection and type I IFN induction. ${ }^{18-22}$ The vital role of NK cells in antiviral defense was first described in the context of murine cytomegalovirus (MCMV) infection of mice, ${ }^{23}$ and later extended to poxvirus species such as ectromelia (mousepox) virus. ${ }^{23-25}$ The contribution of human NK cells to antiviral defense was revealed through the discovery of individuals with heightened susceptibility to virus infections due to deficiencies in the number or function of NK cells. ${ }^{26,27}$ The presence of NK cell receptors, known as killer immunoglobulin-like receptors (KIRs), and their ligands has also been epidemiologically or genetically linked to disease outcomes associated with infections with human cytomegalovirus (HCMV), human immunodeficiency virus (HIV), hepatitis $\mathrm{C}$ virus $(\mathrm{HCV})$, and other viral pathogens. ${ }^{4,28}$ For example, an inhibitory NK cell receptor (KIR2DL3) and its ligand (HLA-C1) were associated with resolution of acute $\mathrm{HCV}$ infection. ${ }^{29}$ In a similar fashion, KIR3DL1 and KIR3DS1 interactions with HLA-B were correlated with a delayed progression to AIDS disease in HIV-infected individuals. ${ }^{30,31}$ These studies indicate that $\mathrm{NK}$ cells contribute to antiviral immunity during some infections; however, the exact contribution(s) of NK cells are not clear due to the confounding ability of $\mathrm{NK}$ cells to contribute to antiviral immunity by regulating other immune cells.

Over the last several years, there have been significant advances in our understanding of NK cells and their long-term influence on adaptive immunity. NK cells can directly interact with T cells, B cells, neutrophils, macrophages, and dendritic cells. There are wide discrepancies between model systems in terms of whether NK cell immunomodulatory activities improve or impair host immunity, in part because NK cell-mediated changes in adaptive immunity can either mediate protection or exacerbate pathogenic outcomes of infection. Moreover, the direct antiviral and indirect regulatory functions of NK cells have been difficult to discriminate in vivo. The complex role of NK cells in pathogenesis of virus infections almost certainly reflects the multi-functional nature of NK cells in a wide range of physiologic processes. This review summarizes recent findings concerning how NK cells influence other immune cell popula- 
tions to enhance or inhibit adaptive immunity, with an emphasis on persistent virus infections.

\section{NK CELL ACTIVATION AND PERSISTENCE AFTER INFECTION}

There is a diverse pool of resident NK cells that are present when infection occurs. The diversity of these NK cells is due to their variegated expression of germ-line encoded activating and inhibitory receptors and their prior exposure to environmental factors. ${ }^{11}$ Before infection, NK cell responses against healthy cells are prevented by NK cell expression of a variety of inhibitory receptors including KIRs, the leukocyte Ig-like receptor 1, Ig-like transcript 2, and CD94/ NKG2A heterodimers in humans; and inhibitory Ly49, KLRG1, and CD94/NKG2A heterodimers in mice. ${ }^{1,32}$ The ligands for these receptors include classical and non-classical MHC molecules and other ligands expressed on healthy cells that protect against aberrant NK cell responses against normal self. ${ }^{33} \mathrm{NK}$ cells also express activating receptors, which recognize stress-induced host receptors and pathogen-derived proteins. Furthermore, a variety of cytokine receptors are expressed by NK cells and can modulate their responses. Following infection, NK cell activity is determined by the net contribution of positive and negative interactions with target or accessory cells mediated by signals from the activating and inhibiting receptors and cytokine receptors.

\section{A. The Activation of NK Cells during Infection}

Broadly speaking, NK cells are activated by three distinct processes: (1) soluble factors including interferons and other cytokines, (2) elevated expression of activating ligands or reduced levels of inhibitory ligands on accessory or target cells, and (3) infectionassociated antigens that directly bind NK cell receptors. ${ }^{6}$ Once activated, NK cells form immunologic synapses with target cells and move lytic granules toward the target, followed by degranulation to kill the target cell. ${ }^{34}$ Alternatively, NK cells may express cytokines (eg, IFN- $\gamma$ or IL-10) to influence the inflammatory environment.

Type- 1 interferons, which are produced within hours of infection, are critical for stimulating NK cell activation and killer activity. ${ }^{18-20,35-37}$ Other factors, such as IL-2, IL-12, IL-15, ${ }^{38-43}$ and IL-18, ${ }^{44-47}$ are also potent activators of NK cells that can work cooperatively to stimulate NK cells. For instance, NK cells are induced to make IFN $\gamma$ through synergistic interactions between IL-18 and IL-12, ${ }^{44,48,49}$ type- 1 interferon and IL-12,50 and IL-2 and IL-12.40,47,51 Different infections stimulate these cytokines to varying extents. For example, NK cells are activated by IL-18 and contact with infected dendritic cells during Listeria monocytogenes infection, ${ }^{52-54}$ whereas many virus infections tend to induce high amounts of IFN- $\alpha / \beta .^{55}$ Thus, NK cell functions likely differ, depending on the nature of the infection and the panel of cytokines that are encountered.

NK cells express an array of inhibitory and activating receptors that modulate their activity (Table 1). ${ }^{1,32,56} \mathrm{NK}$ cells are inhibited by self-ligands that are expressed on healthy cells. However, viruses often target $\mathrm{MHC}$ molecules and reduce their expression to avoid detection by virus-specific CD8+ $\mathrm{T}$ cells. The reduction in $\mathrm{MHC}$ molecules reduces the inhibitory receptor signaling into NK cells, making the NK cells receptive to activation signals. Infected cells also increase their expression of stress-related ligands that engage activating receptors on NK cells. Activating receptors in humans include the natural cytotoxicity receptors NKp46, ${ }^{57,58} \mathrm{NKp} 44,{ }^{59}$ NKp30, ${ }^{60}$ NKG2D, ${ }^{61,62}$ and Fc $\gamma$ RIII (CD16), which recognizes IgG-bound target cells. Similarly, NKp46, DNAM-1 (DNAX accessory molecule-1), NKG2D, CD94/NKG2E, CD94/NKG2C, activating Ly49, and FcyRIII (CD16) stimulate mouse NK cells. The ligands for these activating receptors include stressinduced ligands on activated cells and pathogenderived factors. ${ }^{28,63} \mathrm{NK}$ cell number and function are also influenced by cell-intrinsic processes, including their differentiation state due to prior exposure to inflammatory stimuli, their baseline expression of STATs $^{64,65}$ and their counter-regulators, ${ }^{66}$ and NK cell expression of microRNAs. ${ }^{66-70}$ Importantly, as NK cells respond to infection, their expression of 
TABLE 1. Receptors expressed by NK cells that have been implicated in antiviral responses or in the regulation of adaptive immunity

\begin{tabular}{|c|c|c|c|}
\hline Species & NK cell receptor & Natural cellular ligands & Effect on NK cell activity \\
\hline \multirow{18}{*}{ Human } & NKp30 & B7-H6, BAT3 & Activating \\
\hline & NKp44 & $\begin{array}{l}\text { Heparan sulfate proteoglycan, heparin, } \\
\text { proliferating cell nuclear antigen }\end{array}$ & Activating \\
\hline & NKp46 & $\begin{array}{c}\text { Heparan sulfate proteoglycan, heparin, } \\
\text { vimentin }\end{array}$ & Activating \\
\hline & CD94/NKG2A & HLA-E & Inhibitory \\
\hline & CD94/NKG2C & HLA-E & Activating \\
\hline & NKG2D & MICA/MICB, ULBP1-6 & Activating \\
\hline & KLRG1 & Cadherins $(\mathrm{E}, \mathrm{N}, \mathrm{R})$ & Inhibitory \\
\hline & 2B4 & $\mathrm{CD} 48$ & Activating or Inhibitory \\
\hline & ILT2 & HLA class 1 & Inhibitory \\
\hline & KIR2DS1 & HLA-C & Activating \\
\hline & KIR2DS2 & $? ? ?$ & Activating \\
\hline & KIR2DS4 & HLA-C & Activating \\
\hline & KIR3DS & $? ? ?$ & Activating \\
\hline & KIR2DL2/3 & HLA-C & Inhibitory \\
\hline & KIR3DL1/2 & HLA-A/HLA-B & Inhibitory \\
\hline & DNAM1 & CD155, Nectin-2 & Activating \\
\hline & NTB-A & NTB-A & Activating \\
\hline & CD16 (FcyRIII) & $\mathrm{IgG}$ & Activating \\
\hline \multirow{15}{*}{ Mouse } & NKp46 & ??? & Activating \\
\hline & NK1.1 (NKR-P1A) & Lectin-like transcript-1 & Inhibitory \\
\hline & NKG2D & $\begin{array}{l}\text { RAE-1a, -1b, -1d, -1e, -1g, } \\
\text { H60a-c, MULT1 }\end{array}$ & Activating \\
\hline & CD94/NKG2A & Qa-1 ${ }^{b}$ & Inhibitory \\
\hline & CD94/NKG2C & Qa-1 ${ }^{b}$ & Activating \\
\hline & CD94/NKG2E & Qa-1b & Activating \\
\hline & KLRG1 & Cadherins $(\mathrm{E}, \mathrm{N}, \mathrm{R})$ & Inhibitory \\
\hline & 2B4 & $\mathrm{CD} 48$ & Inhibitory or Activating \\
\hline & Ly49D & H-2Dd & Activating \\
\hline & Ly49H & $? ? ?$ & Activating \\
\hline & Ly49P & $? ? ?$ & Activating \\
\hline & Ly49A & H-2Dd, H-2Dk & Inhibitory \\
\hline & Ly49I & $\mathrm{H}-2 \mathrm{Dk}$ & Inhibitory \\
\hline & DNAM1 & CD155, Nectin-2 & Activating \\
\hline & CD16 (FcyRIII) & $\operatorname{IgG}$ & Activating \\
\hline
\end{tabular}

${ }^{a}$ These reviews by Campbell and Hasegawa, ${ }^{63}$ Lee and Biron, ${ }^{28}$ and Lanier ${ }^{6}$ include a comprehensive list of NK cell receptors. 
activating and inhibiting receptors, cytokine receptors, and signaling molecules evolves, further influencing how the cells respond across time.

As mentioned above, NK cells can directly recognize some proteins of viruses and other pathogens (Table 2). Ly49H/DAP12 heterodimer on NK cells in B6 mice recognizes MCMV-m157, a viral glycoprotein that resembles $\mathrm{MHC} 1$, and contributes to NK cell killing of MCMV-infected cells. ${ }^{71-73} \mathrm{NK}$ cell immunity to MCMV imposes a strong selective pressure on the virus to mutate m157 to evade NK cells. ${ }^{74} \mathrm{NK}$ cells from the $\mathrm{Ma} / \mathrm{My}$ mouse strain are activated by Ly49P/DAP12 heterodimers that recognize $\mathrm{H}-2 \mathrm{Dk}$ molecules on MCMV-infected cells, ${ }^{75}$ leading to NK cell-dependent protection. Other examples include the human NK cell receptors NKp46 and NKp44, which bind to hemagglutinin (HA) from influenza and Newcastle disease viruses, leading to NK cell-mediated lysis of HA-expressing infected cells. ${ }^{76-78} \mathrm{NK}$ cells are also stimulated through NKp44 interactions with envelope glycoproteins from West Nile virus and Dengue virus. ${ }^{79}$

In conjunction with the host evolution involved in viral protein recognition, viruses have evolved mechanisms to avoid activating NK cells. For example, NK cells from the MCMV-susceptible mouse strain, 129/J, recognize m157; however, the interaction is mediated through the inhibitory receptor, Ly49I, leading to suppressed NK cell responses to MCMV. ${ }^{80}$ Several herpesviruses encode MHC-I homolog proteins and proteins that limit expression of NKG2D ligands in an effort to reduce NK cell cytotoxicity of infected cells. ${ }^{81-83} \mathrm{HIV}$-infected cells also selectively downregulate HLA-A and -B which serves to avoid detection by cytotoxic $\mathrm{T}$ cells, but concomitantly maintain HLA-C and -E and thereby protect against NK killing. ${ }^{84,85}$ Other data show that NK cell killing of HIV-infected CD4+ T cells is inhibited through HIV-Vpu-mediated downregulation of NTB-A on the infected cells. ${ }^{86,87}$ Multiple viruses target the NK cell activating receptor $\mathrm{NKp30}$ to prevent cytotoxicity. The HCMV pp65 protein binds to NKp30 and prevents NKp30-mediated NK cell activation. ${ }^{88}$ Likewise, liver NK cells are impaired in function in $\mathrm{HCV}$-infected individuals, ${ }^{89}$ in part through $\mathrm{HCV}$-mediated downregulation of
NKp30. ${ }^{90} \mathrm{HCV}$-infected cells can also inhibit NK cell cytotoxicity and cytokine production by expressing $\mathrm{HCV}$-envelope that binds CD81 on NK cells, ${ }^{91,92}$ or by HCV-core peptide mediated stabilization of HLA-E to inhibit NK cells through NKG2A. ${ }^{93}$ In addition to interfering with $\mathrm{NK}$ cell receptor functions, certain viral proteins impact cytokine signaling as well, i.e., IL-10 homologs and IL-18 binding proteins. ${ }^{94-97}$ The ability of viruses to evade NK cells likely arose due to selective pressures and indicates the critical role for NK cells in eliminating infections; for more detail please see these reviews. ${ }^{98,99}$

\section{B. "Memory" NK Cells}

One of the biggest recent discoveries is that NK cells have memory-like phenotypes where their frequency and differentiation status is maintained for an extended time (Table 3). Typically, in uninfected mice NK cells are thought to survive 7-14 days. ${ }^{3,100-103}$ However, it has been observed that HCMV induces a long-lasting selection for subsets of NK cells expressing particular KIRs. ${ }^{104}$ Other data show that a subset of FcRgamma-deficient NK cells persist for extended times in individuals with HCMV infection, and the cells exhibit enhanced functional abilities when compared to conventional NK cells. ${ }^{105}$ Memory NK cells have been detected in MCMV and genital herpes virus infections in mice, ${ }^{103,106}$ and in people exposed to HCMV or hantavirus. ${ }^{107,108}$ Liver NK cells that were sensitized to haptens in $\mathrm{T}$ cell-deficient and B cell-deficient mice could be transferred to new mice and mediate hapten-specific ear swelling 4 weeks later. ${ }^{109}$ Liver NK cells isolated from mice vaccinated with influenza virus-like particles or UV-inactivated VSV could transfer protection to naïve mice and protect the mice against lethal virus challenge. ${ }^{109}$ Following primary infection with MCMV, activated NK cells show a slow decay in frequency, so that an increased number of activated NK cells is still observable for $\sim 2$ months after initial infection. ${ }^{110}$ The term "memory" applied to sustained populations of NK cells is ambiguous in the setting of latent herpesviruses, since the NK cells may be restimulated by reactivating virus as opposed 
TABLE 2. NK cells directly recognize virus-encoded ligands or cellular ligands that are modulated by virus infection. ${ }^{\mathrm{a}}$

\begin{tabular}{|c|c|c|c|}
\hline Species & Virus & $\begin{array}{c}\text { Viral ligand or virus-modulated cellular } \\
\text { ligands }\end{array}$ & NK cell receptor \\
\hline \multirow[t]{21}{*}{ Human } & \multirow[t]{5}{*}{ HCMV } & HLA-E & CD94/NKG2C \\
\hline & & Cell stress ligands: MICA/B, ULBP1-4b & NKG2D \\
\hline & & pp65 & NKp30 \\
\hline & & UL18 & LILRB1 \\
\hline & & $? ? ?$ & $\begin{array}{l}\text { KIR2DS4, KIR2DS2, } \\
\text { KIR3DS1 }\end{array}$ \\
\hline & HSV & $\begin{array}{c}\text { Unknown but associated with ICP0 } \\
\text { expression }\end{array}$ & NKp30, NKp40, NKp46 \\
\hline & EBV & HLA-C & KIR2DS1 \\
\hline & Ectromelia virus & HA & NKp30, NKp46 \\
\hline & Vaccinia virus & HA & NKp30, NKp46 \\
\hline & Dengue virus & Envelope-protein & NKp44 \\
\hline & West Nile virus & Envelope-protein, HA-neuraminidase & NKp44 \\
\hline & Influenza A virus & HA, HA-neuraminidase & NKp44, NKp46 \\
\hline & $\begin{array}{l}\text { Human parainfluenza } \\
\text { virus }\end{array}$ & HA-neuraminidase & NKp46 \\
\hline & Sendai virus & HA, HA-neuraminidase & NKp44, NKp46 \\
\hline & $\begin{array}{c}\text { Newcastle disease } \\
\text { virus }\end{array}$ & HA, HA-neuraminidase & NKp44, NKp46 \\
\hline & Ebola virus & $? ? ?$ & NKp30 \\
\hline & \multirow[t]{2}{*}{$\mathrm{HCV}$} & $? ? ?$ & $\begin{array}{l}\text { NKp30, NKp46, } \\
\text { CD94/NKG2C }\end{array}$ \\
\hline & & E2 & $\mathrm{CD} 81$ \\
\hline & \multirow[t]{3}{*}{ HIV } & HLA-B & KIR3DS1 \\
\hline & & $? ? ?$ & NKp44, NKp46 \\
\hline & & Vpu reduces NTB-Ac $^{\mathrm{c}}$ & NTB-A \\
\hline \multirow[t]{7}{*}{ Mouse } & \multirow[t]{5}{*}{ MCMV } & $\mathrm{m} 157$ & $\begin{array}{l}\text { Ly49H/DAP12 } \\
\text { (C57BL/6) }\end{array}$ \\
\hline & & $\mathrm{m} 157$ & Ly49I (129) \\
\hline & & H-2D ${ }^{k}$ with m04 & Ly49P/DAP12 \\
\hline & & $\begin{array}{c}\text { Virus-induced cell stress ligands: Rae1, } \\
\text { H60a-c, Mult } 1^{\mathrm{b}}\end{array}$ & NKG2D \\
\hline & & $\mathrm{m} 154$ reduces $\mathrm{CD} 48^{\mathrm{c}}$ & 2B4 \\
\hline & Ectromelia virus & Qa-1 ${ }^{\mathrm{b}}$ & CD94/NKG2E \\
\hline & Influenza A virus & HA & NKp46 \\
\hline
\end{tabular}

aPlease see these reviews of NK cell recognition of viral ligands. ${ }^{28,269}$

${ }^{\mathrm{b}}$ Cell stress ligands are induced when cells are infected.

${ }^{c}$ This cellular ligand is downregulated by a viral protein leading to less NK cell activation. 
TABLE 3. Receptors implicated in NK cell memory.

\begin{tabular}{|c|c|c|c|}
\hline & NK cell Receptor & Species & Notes \\
\hline \multirow[t]{5}{*}{$\begin{array}{l}\text { Virus infectionin- } \\
\text { duced memory }\end{array}$} & CD94/NKG2C+ CD57+ & Human & $\begin{array}{l}\text { Heightened reactivity to putative HCMV } \\
\text { ligand(s). Other activating KIRs may be } \\
\text { involved. This subset of NK cells is also } \\
\text { expanded following hantavirus infection. }\end{array}$ \\
\hline & $\begin{array}{c}\text { KIR2DS4, KIR2DS2, } \\
\text { KIR3DS1 }\end{array}$ & Human & $\begin{array}{l}\text { NK cells expressing these activating receptors } \\
\text { are clonally expanded following HCMV but } \\
\text { not other herpesvirus infections. }\end{array}$ \\
\hline & Ly49H+/DAP12 & Mouse & $\begin{array}{l}\text { Confers specificity to } \mathrm{m} 157 \text { ligand and } \\
\text { requisite signaling. Associated with memory to } \\
\text { MCMV. }\end{array}$ \\
\hline & DNAM-1 & Mouse & $\begin{array}{c}\text { Induces Fyn/PKCn signaling to potentiate } \\
\text { Ly49H/DAP12 signals to allow memory to } \\
\text { MCMV }\end{array}$ \\
\hline & CXCR6+ & Mouse & $\begin{array}{l}\text { Vaccines can induce long-lived pools of liver- } \\
\text { homing NK cells that can quickly respond to } \\
\text { live influenza challenge. Other virus-binding } \\
\text { receptors may be involved. }\end{array}$ \\
\hline $\begin{array}{l}\text { Cytokine-induced } \\
\text { memory }\end{array}$ & IL-12R, IL-15R, IL-18R & $\begin{array}{l}\text { Human and } \\
\text { Mouse }\end{array}$ & $\begin{array}{l}\text { In vitro stimulation with these cytokines } \\
\text { induces a pool of long-lived NK cells } \\
\text { that are maintained in vivo with enhanced } \\
\text { cytokine reactivity and can kill tumor cells. } \\
\text { Similarly, virus-induced mature NK cells } \\
\text { undergo homeostatic cell division, establish } \\
\text { a long-lived pool of cells, and maintain } \\
\text { enhanced antiviral reactivity when placed into } \\
\text { lymphopenic hosts. }\end{array}$ \\
\hline $\begin{array}{l}\text { Hapten-induced } \\
\text { memory }\end{array}$ & NKG2D+ CXCR6+ & Mouse & These memory NK cells localize to the liver. \\
\hline
\end{tabular}

to persisting in a quiescent state. Nevertheless, it may be a general finding that herpesvirus infections result in activated NK cell populations that are elevated in number and sustained for extended periods of time.

There is evidence that pro-inflammatory cytokines are involved in the induction of memory NK cells. Human ${ }^{111}$ and mouse ${ }^{112,113}$ NK cells can be stimulated by cytokines to have memory-like responses. For example, in vitro stimulation of NK cells with IL-12/IL-18/IL-15 enables them to survive several weeks upon transfer into uninfected mice, ${ }^{112,113}$ and these cells retain their ability to respond to tumors. ${ }^{112}$ Other data show that MCMV-induced "memory" NK cells are dependent on proinflammatory cytokine signaling, in particular IL-12 and STAT4. ${ }^{114}$ Lymphopenia induces activation marker expression on NK cells, which is due to the increased abundance of IL-7 and IL-15 cytokines. Adoptive transfers of resting or activated NK into lymphopenic hosts demonstrated that cytokine-induced memory-like responses are maintained by homeostatic proliferation. ${ }^{115}$ These and other data indicate that experienced NK cells give rise to descendant populations that are epigenetically imprinted to express activation markers and rapid effector functions and are distinct from authentic naïve NK cells. ${ }^{116}$

Most studies have examined memory NK cells during latent virus infection or have followed 
cytokine-mediated NK cell longevity. Further studies are needed to explore how general those findings are. For example, do many memory NK cells develop following acute virus infection and how are those cells induced and maintained when inflammatory signals are transient? It is still not well defined how beneficial these memory NK cells are to the host. Some evidence shows that the presence of expanded populations of activated NK cells can be protective against homologous virus challenge. ${ }^{109}$ There is also evidence that elevated populations of NK cells can protect against heterologous challenges through bystander processes, although the underlying mechanisms are unclear. For example, mice with an elevated population of activated NK cells due to MCMV infection were better protected against co-infection with friend virus than $\mathrm{MCMV}$-naïve mice. ${ }^{117} \mathrm{~A}$ similar effect was also seen following latent murid herpesvirus 4 infection, as the persistence of cytolytic IFN $\gamma+\mathrm{NK}$ cells protected against a lymphoma challenge. ${ }^{118}$ The role of "memory" NK cells in immune protection is an exciting area, and further analyses are needed to explain how the presence of "memory" NK cells confers better protection than naïve NK cells.

\section{NK Cell Responses during Persistent Virus Infections}

NK cells respond within hours of infection, often preceding $\mathrm{T}$ cell responses, but the responses can be concurrent, especially when the virus establishes persistence. We compared NK cell responses in mice that were either acutely infected with LCMVArmstrong or given a disseminating infection with LCMV-Clone13. ${ }^{119}$ These two strains of LCMV cause very different infections that depend in part upon the size of initial inoculum. Armstrong infection induces an interferon burst from plasmacytoid DCs at 18 hours followed by interferon production for 2-3 days from other infected target cells (macrophages and dendritic cells). ${ }^{120}$ The virus is eliminated within a week by vigorously proliferating cytolytic $\mathrm{CD} 8+\mathrm{T}$ cells. In contrast, LCMV-Clone13 infection disseminates widely, infects additional populations of cells, including CD4+ DC and reticular endothelial cells, ${ }^{121-124}$ and induces a larger amount of IFN that is sustained. ${ }^{120,125,126}$ Both Armstrong and clone 13 infections induce NK cell maturation to a similar extent, as measured by CD11b, CD27, and KLRG-1 expression. ${ }^{119}$ However, the frequency of NK cells within the blood and their expression of granzyme $\mathrm{B}$ are higher during the chronic viral infection. ${ }^{119}$ Persistent clone 13 infection also induces the accumulation of CD127+ NK cells that are responsive to IL-2 stimulation. ${ }^{127}$ Increased percentages of activated NK cells are also observed in HIV-infected patients, ${ }^{128}$ and highly activated hepatic NK cells are associated with severe hepatitis $\mathrm{C}$ virus-induced pathology. ${ }^{129}$ Thus, NK cells are activated early after infection, but an increased abundance of NK cells is evident for extended periods of time in association with persistent virus.

NK cells that are present at later times during chronic infection may function similarly or differently from the NK cells that are induced soon after initial infection or the "memory" NK cells that persist after the resolution of an acute infection. Some evidence shows there is an expanded population of dysfunctional NK cells in HIV+ patients that exhibit major alterations in expression of activation markers, cytokine production, and cytolytic function. ${ }^{130-133} \mathrm{It}$ has been hypothesized that these changes in NK cells contribute to the generalized immune deficiency during HIV infection by perturbing dendritic cell function and inhibiting T cell responses. ${ }^{133,134}$ Furthermore, NK cells mediate cytotoxicity against HIVinfected CD4+ $\mathrm{T}$ cells, potentially contributing to the loss of this vital cell population. ${ }^{128,135}$ Additionally, there is a reduction in NK cell frequencies in chronic $\mathrm{HCV}$ - and $\mathrm{HBV}$-infected individuals compared to healthy individuals or spontaneous resolvers. ${ }^{136-139}$ Successful antiviral therapy for HCV leads to an increase in NK cell frequency and function, ${ }^{140,141}$ consistent with a direct role for NK cells in limiting $\mathrm{HCV}$ replication. Thus, NK cells play a central role in immune defense during persisting virus infections in humans. This is best seen in HIV where immune pressure by NK cells has selected for HIV amino acid polymorphisms only in individuals who have the NK cell receptor KIR2DL2. ${ }^{142}$ 
Despite their importance, the specific roles of NK cells and their immune-modulating functions are not completely understood. Antiviral NK and $\mathrm{T}$ cell responses occur at similar times and in similar locations, especially during persistent viral infections. In mouse models of chronic infection there is evidence that NK cells limit T cell responses. For example, NK cell depletion during the chronic stage of LCMV infection enhanced antiviral $T$ cell responses, depending in part upon the viral load at the time of depletion and the presence of CD4+ T cells. ${ }^{143}$ Understanding how NK cells affect $\mathrm{T}$ cells at different stages of infection is relevant in designing new treatments for chronic viral infections, particularly $\mathrm{HIV}$ and $\mathrm{HCV}$, where there are perturbations in NK cell frequency and function. As discussed below, NK cells can enhance or impede $T$ cell responses through a variety of different mechanisms.

\section{NK CELLS INFLUENCE T CELL RESPONSES TO INFECTION}

NK cells become activated following infections, and can contribute to host immunity by killing infected cells and making antiviral cytokines, such as IFN- $\gamma$. While the direct antiviral role of NK cells is fairly well defined in murine CMV and ectromelia virus infections, it is difficult to discriminate among the variety of potential NK cell contributions to antiviral immunity in other infections in mice and humans. For example, though it is clear from the recurrent infections that plague patients with genetic deficiencies in NK cells numbers or functions that NK cells are important, ${ }^{26}$ it remains unclear whether this can be attributed to NK cell lysis of infected cells, the contribution of NK cell-derived IFN- $\gamma$ to subsequent immune reactions, the NK cell curtailing of excessive immune responses that could damage host tissues, or a combination of these activities. In most infections, the contributions of NK cells probably comprise a complex combination of these activities and their principle function for many infections is to reduce virus load. However, NK cells influence adaptive immune responses through a variety of mechanisms. NK cells can affect $T$ cells directly by releasing or consuming cytokines or by killing $\mathrm{T}$ cells. NK cells can influence $\mathrm{T}$ cells through indirect mechanisms such as by regulating APC activity. This section highlights the various ways in which NK cells are capable of positively or negatively altering $\mathrm{T}$ cell responses.

\section{A. Cytokine Production by NK Cells}

Though originally identified and named based on their ability to directly lyse target cells, the production of cytokines by NK cells is a separate effector function that can have direct effects on $\mathrm{T}$ cell responses [Figs. 1(A) and 1(B)]. The signature cytokine produced by NK cells is IFN- $\gamma$, which can be made very rapidly (2-4 hours) upon activation. ${ }^{144,145}$ In addition to its role in virus control, IFN- $\gamma$ has direct effects on primary and memory CD4+ and CD8+ T cell expansion. ${ }^{146-148}$ During Leishmania major infection and DC-based priming experiments, the production of IFN- $\gamma$ by NK cells was essential for driving Th1 cell differentiation. ${ }^{149,150}$ Additionally, NK cells were shown to be important for CD8+ T cell responses to influenza infection, and one mechanism responsible for this was IFN- $\gamma$-dependent recruitment of CD8+ T cells to the lymph node. ${ }^{151,152}$ These effects all have a positive influence on $\mathrm{T}$ cells, but NK cells can also negatively influence $\mathrm{T}$ cells, particularly through IL-10 and TGF- $\beta$ production. ${ }^{153,154}$ IL-10 is an antiinflammatory cytokine often produced by regulatory $\mathrm{T}$ cells (Treg) cells that can directly suppress $\mathrm{T}$ cell responses. ${ }^{155,156}$ A population of human regulatory NK cells has been described that produces IL-10 and reduces the in vitro proliferation of antigen-specific CD4+ T cells. ${ }^{157}$ Immunosuppressive IL-10 producing NK cells have also been detected in multiple systemic bacterial infections in mice including Toxoplasma gondii, Listeria monocytogenes, and Yersinia pestis. ${ }^{158}$ These cells were dependent on IL-12 for their generation and were not found using attenuated strains that elicit local infections, suggesting that the nature of the pathogen shapes the NK cell response. Furthermore, MCMV infection of perforin-deficient mice led to a persistent infection and the generation of IL-10-producing NK cells that limit CD8+ T cell effector functions. ${ }^{159}$ Interestingly, patients with chronic hepatitis $\mathrm{C}$ virus infec- 
tion have increased frequencies of IL-10-producing NK cells and these cells may also contribute to poor immunity during HIV infection. ${ }^{160-162}$ Thus, these studies point to a model wherein the IL-10-mediated regulatory capability of $\mathrm{NK}$ cells is triggered during disseminating infections in an effort to protect against $\mathrm{T}$ cell-mediated immunopathology.

\section{B. Competition for Cytokines}

Another mechanism through which NK cells may impact $\mathrm{T}$ cell responses is by competition for limiting amounts of cytokines [Fig. 1(C)]. NK cells and $\mathrm{T}$ cells express many of the same cytokine receptors, including but not limited to those for IFN $-\alpha / \beta$, IFN- $\gamma$, IL-2, IL-12, and IL-15.3,163-165 These cytokines are often crucial for the expansion of primary and memory $\mathrm{T}$ cell responses and can also influence $\mathrm{T}$ cell differentiation. In particular, direct competition for IL-2 is known to occur between effector T cells and Tregs. ${ }^{166}$ Treg cells constitutively express CD25, the high affinity subunit of the IL-2 receptor, and can induce apoptosis of CD4+ T cells through cytokine deprivation. ${ }^{167}$ Interestingly, rapid upregulation of CD25 by NK cells is observed during MCMV infection and contributes to their expansion. ${ }^{168}$ These data suggest that NK cells and T cells may directly compete for IL-2, though there have not been many reports directly testing this hypothesis. Some evidence supporting this theory is that in the absence of a CD8+ T cell response against LCMV-Armstrong in $\beta 2 \mathrm{M}-/-$ mice, there is a significant IL-2-dependent increase in the frequency of NK cells. ${ }^{169} \mathrm{~A}$ possible interpretation of these data is that NK cells and T cells compete for IL-2, with the $\mathrm{T}$ cells having the advantage in WT animals. Additionally, NK cells have been shown to limit the homeostatic proliferation of CD8+ T cells in lymphopenic hosts. ${ }^{170}$ This effect is independent of NK cell perforin expression and reversed by addition of excess IL-15, showing that NK cells and T cells compete for limiting levels of IL-15. Further testing of this cytokine competition hypothesis is needed to understand its importance during infectious disease.

\section{Direct Lysis of T Cells by NK Cells}

The ability of NK cells to directly lyse $\mathrm{T}$ cells has been known for some time, though only recently have the consequences started to be understood. One of the first documented in vivo targets for NK cells was thymocytes, ${ }^{171}$ and YAC-1 cells, which are commonly used in NK cell cytotoxicity experiments, are T cell lymphoma cells. While NK cells are capable of lysing thymocytes, ${ }^{172}$ this is typically prevented by thymocyte expression of $\mathrm{MHC}-1 .{ }^{173}$ In addition to MHC-I, mature T cells express many ligands for both activating and inhibitory NK cell receptors, and the dynamic regulation of their expression can affect the outcome of their interactions with NK cells. Recently, many studies have identified these key molecules involved in NK cell-mediated lysis of T cells and have started to uncover the physiological effects of this process during infection. As this section shows, $\mathrm{T}$ cell lysis can have positive or negative effects on pathogen clearance and protection from immunopathology.

\section{Regulation of T Cell Lysis by NK Cell Activating Receptors}

The recognition and lysis of both mouse and human T cells through NK cell activating receptors has been shown by a handful of studies [Fig. 1(D)]. ${ }^{174-177} \mathrm{~A}$ consistent finding is that naïve cells are protected from killing while activated cells can be susceptible. One explanation for the increased lysis of activated $T$ cells is through the upregulation of NKG2D ligands. NKG2D is a homodimeric receptor with multiple ligands expressed by all NK cells in mice and humans, though the expression patterns on other cell types vary between species. ${ }^{178-180}$ The cross-linking of NKG2D in human and mouse NK cells results in the enhancement of NK cell-mediated cytotoxicity. ${ }^{181}$ Cerboni et al. showed that upon activation, human CD4+ and CD8+ T cells upregulate surface expression of the NKG2D ligands MICA, ULBP1, ULBP2, and ULBP3 (Table 4). ${ }^{175}$ The activated T cells were then killed by autologous IL-2-activated NK cells in a NKG2D-dependent fashion, as the addition of 
A. NK cell secretion of IFN- $\gamma$ promotes T cell responses

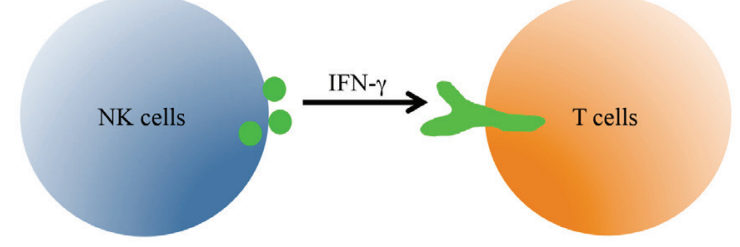

B. NK cell production of IL-10 inhibits T cell responses

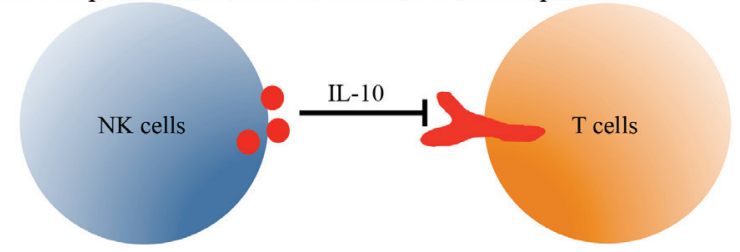

C. NK cells outcompete T cells for survival cytokines

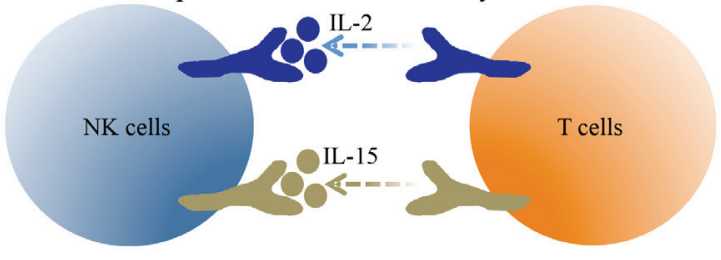

D. NK cells directly kill activated T cells

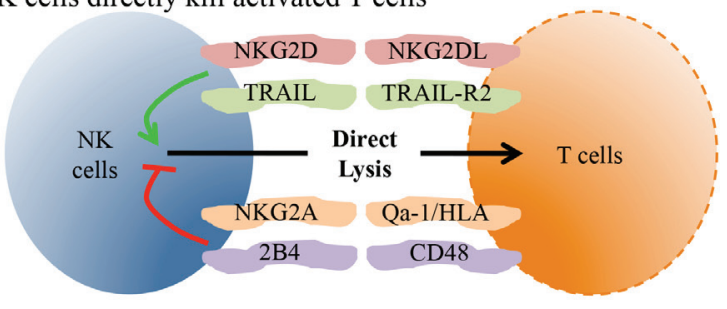

FIG. 1: NK cells regulate T cells through direct mechanisms. NK cells are located near virus-specific T cells and influence their activity and number. (A) Activated NK cells make IFN- $\gamma$ that can directly signal into $T$ cells to stimulate their accumulation and differentiation into effector and memory cells. (B) During some persisting virus infections, NK cells make IL-10 that limits $\mathrm{T}$ cell proliferation and effector cytokine production. (C) Virus-specific T cells need IL-2 and IL-15 signals during multiple stages of the T cell response. Activated NK cells express high levels of IL-2R and IL-15R and compete with virus-specific $\mathrm{T}$ cells for these vital survival cytokines. (D) NK cells can directly interact with effector $\mathrm{T}$ cells through multiple molecular interactions. NK cells can focus their cytolytic activity onto T cells when the balance of positive and inhibitory signals results in NK cell stimulation.

an anti-NKG2D neutralizing antibody completely abrogated killing. Further testing using human cells showed that both CD56 $6^{\mathrm{dim}}$ and CD56 $6^{\text {bright }} \mathrm{NK}$ cells are capable of mediating lysis of activated CD4+ T cells via NKG2D. ${ }^{177}$

These data are consistent with data obtained using in vitro activated mouse $\mathrm{T}$ cells that are also lysed by NK cells via NKG2D. ${ }^{174}$ Additionally, in vivo data show that the amount of memory CD8+ $\mathrm{T}$ cells following immunization is significantly higher in NK cell-depleted mice. ${ }^{176}$ This effect is dependent on NKG2D and perforin, implying a direct effect of the NK cells on T cells. Taken together, these data clearly show that activated $\mathrm{T}$ cells can become susceptible to lysis by NK cells in humans and mice through the upregulation of ligands for NKG2D, and that this can have longlasting effects on $\mathrm{T}$ cell responses.

In addition to NKG2D, NK cells express a number of other activating receptors. For example, a receptor known to be involved in the lysis of CD4+ T cells is TNF-related apoptosis-inducing ligand (TRAIL). ${ }^{177}$ Similar to NKG2D ligands, the expression of TRAIL-R1 and -R2 are induced upon activation by naïve $\mathrm{T}$ cells. ${ }^{177}$ TRAIL-expressing NK cells induced apoptosis through TRAIL-R1 and TRAIL-R2 to selectively kill only activated T cells. ${ }^{177}$ This study also showed a heterogeneity in the ability of NK cells to mediate killing, as only the CD56 bright subset of NK cells are capable of using this TRAIL-dependent pathway. ${ }^{177}$ In addition, as discussed below in Sec. 3, CD8+T cells from patients chronically infected with HBV have also been shown to express TRAIL-R2. ${ }^{182}$ Therefore, TRAIL is a NK cell receptor involved in direct recognition and subsequent death of $\mathrm{T}$ cells. Further experiments are needed to fully understand the contributions of any other NK cell activating receptors that may be involved in the regulation of $\mathrm{T}$ cell responses.

Ironically, the direct lysis of T cell subsets by NK cells may also promote other $\mathrm{T}$ cell responses. In in vitro experiments, activated Treg cells upregulated the NKG2D ligand UL16-binding protein 1 and became susceptible to NK cell lysis. ${ }^{183}$ Though further studies are needed to assess the relevancy of this finding in vivo, the potential for NK cells to promote effector $\mathrm{T}$ cell responses by ablating Treg cells is intriguing. 
TABLE 4: NK cell interactions affect virus-specific $T$ cell responses through direct and indirect mechanisms.

\begin{tabular}{c|c|c|c|c}
\hline $\begin{array}{c}\text { Intercellular } \\
\text { interaction }\end{array}$ & NK cell receptor & TargeT cell ligand & Species & Outcome \\
\hline \multirow{4}{*}{ NK-T cell } & NKG2D & MICA, ULBP1-3 & Human & TargeT cell lysis \\
\cline { 2 - 5 } & TRAIL & RAE-1, MULT-1 & Mouse & TargeT cell lysis \\
\cline { 2 - 5 } & NKG2A/CD94 & HLA-E & Human & TargeT cell lysis \\
\cline { 2 - 5 } & & Qa-1 & Block lysis \\
\cline { 2 - 5 } & 2B4 & CD48 & Mouse & Block lysis \\
\hline \multirow{4}{*}{ NK-DC } & NKp30 & BAT3 & Human & Block lysis \\
\cline { 2 - 5 } & NKG2D & $?$ & Activates DCs \\
\cline { 2 - 5 } & DNAM-1 & Nectin-2, CD155 & $\begin{array}{c}\text { Human, } \\
\text { mouse }\end{array}$ & Activates DCs \\
\cline { 2 - 5 } & NKp30 & DC lysis \\
\cline { 2 - 5 } & NKG2A/CD94 & HLA-E & Human & DC lysis \\
\hline
\end{tabular}

\section{Regulation of T Cell Lysis by NK Cell Inhibitory Receptors}

In addition to the effects of NK cell activating receptors, inhibitory NK cell receptors have also been shown to regulate NK cell-mediated $\mathrm{T}$ cell lysis [Fig. 1(D), Table 4]. In most cases, activated T cells express the ligands for these inhibitory receptors to protect themselves from NK cell-mediated killing. In the steady state, $\mathrm{T}$ cell expression of MHC-I molecules can protect against basal NK cell activity. Upon activation, human CD4+ T cells rapidly upregulate HLA-E, a ligand for NKG2A. ${ }^{184}$ This interaction was shown to be protective as blocking antibodies to either NKG2A or HLA-class I resulted in greatly increased NK cell killing. ${ }^{177,184}$ The homolog to HLA-E in mice is Qa-1, which is primarily found presenting the Qdm peptide and interacts with NKG2A to deliver an inhibitory signal. Using either Qa1-knockout mice or a Qa1 mutant that is unable to bind to NKG2A, a study showed that this interaction was critical for protecting $\mathrm{T}$ cells from NK cell lysis in vivo. ${ }^{185}$ Importantly, a blocking antibody to Qa1 reduces the extent of paralysis in a CD4 T cell-mediated autoimmune disease model, experimental autoimmune encephalomyelitis, in an NK-dependent manner. ${ }^{185}$ NK cell-dependent regulation of T cells has been seen in other autoimmune models. For example, depletion of NK cells accelerates CD4 $\mathrm{T}$ cell-mediated disease induction in a colitis model. ${ }^{186}$ Also, anti-NKG2A F(ab)'2 treatment, which blocks this inhibitory receptor on NK cells, led to improved NK cell-mediated killing of pathogenic CD4+ $\mathrm{T}$ cell responses in a collageninduced arthritis model. ${ }^{187}$ Finally, NK cell depletion accelerates colitis in a model where disease is mediated by CD4+ T cells. ${ }^{186}$ In summary, these data using knockout mice and blocking antibodies have shown that $\mathrm{T}$ cell expression of ligands for inhibitory receptors protects them against NK cell lysis. These findings highlight the potential of NK cells as therapeutic targets during autoimmune diseases or overactive responses to infection wherein lysis of $\mathrm{T}$ cells may significantly ameliorate symptoms.

\section{T Cell Lysis during Chronic Viral Infections}

The in vivo ability of NK cells to directly regulate $\mathrm{T}$ cell responses has been shown recently in a mouse model of chronic viral infection with LCMV. ${ }^{188,189}$ 
While these two studies came to different conclusions regarding the nature of the cells targeted by NK cellmediated regulatory activities, they agree that $\mathrm{CD} 8+$ $\mathrm{T}$ cell responses are enhanced in the absence of NK cells. Lang et al. use NK cell deficient (Nfil3- or E4bp4knockout) mice to show that CD8+ T cells are regulated by NK cells in a perforin-dependent fashion. ${ }^{189}$ This enhanced $\mathrm{T}$ cell response results in clearance of a viral strain that typically establishes persistence. Building on an earlier study that provided evidence that NK cells inhibit CD4+ T cell responses, ${ }^{190}$ the study by Waggoner et al. showed that NK cells restrict $\mathrm{CD} 8+\mathrm{T}$ cell responses by targeting CD4+ T cells, ${ }^{188}$ which are essential for sustaining $\mathrm{CD} 8+\mathrm{T}$ cells during this infection. ${ }^{188,191-194}$ Using an in vivo cytotoxicity assay, it was observed that activated CD4+ but not CD8+ $\mathrm{T}$ cells are direct targets of NK cell lysis in a perforin-dependent manner. ${ }^{195}$ Although the exact mechanism which allows NK cells to discriminate between different $\mathrm{T}$ cell targets is not known, accumulating evidence suggests that interactions between 2B4/CD244 on NK cells and CD48 on T cells may play an important role. Specifically, CD48 expression was upregulated after activation of murine $\mathrm{T}$ cells, wherein activated CD8+ $\mathrm{T}$ cells expressed much higher levels of this receptor than their activated CD4+ T cell counterparts. ${ }^{195}$ While $2 \mathrm{~B} 4$ is capable of mediating both activating and inhibitory signaling in NK cells, ${ }^{196,198}$ genetic ablation of this receptor in mice resulted in an increase in NK cell activity, particularly against CD48-expressing targets. ${ }^{199,200}$ This suggests that the elevated expression of CD48 on activated CD8+ T cells may impair NK cell cytolysis better than the level of CD48 expressed on activated CD4 $\mathrm{T}$ cells, and thereby contribute to differential killing. In fact, removal of 2B4 from NK cells or CD48 from T cells resulted in enhanced NK cell-mediated killing of activated CD8 T cells. ${ }^{195}$

Interestingly, in this study the consequences of the NK cell activity varied depending on the amount of virus given to the mice. The LCMV-Clone13 strain disseminates widely and establishes persisting infection whereas LCMV-Armstrong causes an acute infection. At a low virus dose of LCMV-Clone13, or when using LCMV-Armstrong, there is a small effect of NK cell depletion on T cell responses in WT mice, though little pathogenesis is detected in the presence or absence of NK cells. ${ }^{119,188-190}$ However, when given a medium dose of LCMV-Clone13, the mice succumb to a $\mathrm{T}$ cell-mediated disease. ${ }^{188}$ The removal of NK cells after anti-NK1.1 antibody injection results in enhanced $\mathrm{T}$ cell responses and prevents the fatal immune-mediated pathogenesis as the virus is cleared from the animals. In contrast, at a high dose of virus inoculum the NK cells contribute towards T cell dysfunction and host protection. At this dose of virus, the infection quickly spreads throughout the animal and into vital tissues. NK cell depletion in mice infected with a high dose of LCMV-Clone 13 increases the $\mathrm{T}$ cell number to a level where $T$ cells respond excessively against the virus, leading to immune-mediated pathogenesis. These data show that NK cells are capable of severely limiting $\mathrm{T}$ cell responses and, depending on the strain and amount of virus present, can contribute towards protecting the host from fatal immunopathogenesis. ${ }^{188}$

In addition to the mouse models of infection, a recent report showed evidence for direct NK cellmediated lysis of $\mathrm{T}$ cells in chronic HBV-infected patients. ${ }^{182}$ The peripheral and intrahepatic CD8+ $\mathrm{T}$ cells from these patients expressed higher levels of TRAIL-R2, ${ }^{182}$ which is a death receptor that results in caspase-8-mediated apoptosis when triggered. ${ }^{182,201}$ TRAIL, the ligand for TRAIL-R2, was already known to be upregulated on NK cells during $\mathrm{HBV}$-related liver inflammation. ${ }^{202,203}$ Culturing the T cells with NK cells induced contact-dependent apoptosis, which was partially reduced by the blockade of TRAIL. ${ }^{182}$ These data suggest that NK cells may directly limit the antiviral capabilities of CD8+ T cells during chronic HBV infection. Thus, it appears that in both mice and humans NK cells regulate $\mathrm{T}$ cell responses during chronic virus infections to protect the host from immune-mediated damage, leading to prolonged virus persistence.

\section{NK Cells Affect Dendritic Cells to Influence T Cells}

Dendritic cells (DCs) are the primary cells responsible for initiating $\mathrm{T}$ cell activation through the presenta- 
tion of foreign peptides on MHC molecules. ${ }^{204} \mathrm{As}$ such, the regulation of DCs by NK cells can have significant effects on the T cell response. NK cells and DCs are activated early during immune responses and subsets of each localize to lymphoid organs. In fact, intravital imaging shows that NK cells directly interact with lymph node DCs in vivo. ${ }^{205}$ The cross talk between these cells is complex and also crucial in determining the outcome of adaptive immune responses. Both cell types produce cytokines that can activate or inhibit the other cell type and their cellcell interactions can lead to either death or enhanced activation. The following section highlights the ability of NK cells to modulate DC activity and the positive and negative effects of this on $\mathrm{T}$ cell responses.

\section{Positive Effects of NK Cells on DCs}

The interactions between NK cells and DCs can have either positive or negative effects on the subsequent priming of $\mathrm{T}$ cell responses (Table 4). Many of the studies showing that NK cells promote $\mathrm{DC}$ activation were done in vitro using human cells. The co-culture of DCs with activated NK cells results in upregulation of MHC-II and the co-stimulatory molecules CD80, CD83, and CD86, and increased production of the pro-inflammatory cytokine IL-12 [Fig. 2(A)]. ${ }^{206,207}$ As expected, the increased DC maturation results in an enhanced ability of DCs to stimulate $\mathrm{T}$ cell expansion. ${ }^{207}$ The induction of DC maturation was initially shown to be dependent on cell-cell contact with the NK cells, as well as on NK cell-mediated production of IFN- $\gamma$ and TNF- $\alpha .^{206,207}$ Further studies showed that the NK cell activating receptor NKp30 was also involved in this process. ${ }^{208}$ NKp30 has multiple known ligands, though the only one thought to be expressed by DCs is HLA-B-associated transcript 3 (Bat3). ${ }^{209}$ Additionally, DC production of IL-18 triggers NK cell secretion of high-mobility group protein $\mathrm{B} 1$ (HMGB1) that acts on $\mathrm{DC}$ to promote their maturation. ${ }^{210}$ Changing the NK-DC ratio can also critically regulate the ability of NK cells to induce DC maturation, as a low NK-DC ratio is favorable for this process. ${ }^{206}$ However, the effects of the changes in this ratio that occur during infection in vivo are not understood. Taken together, these data clearly show that NK cells can enhance the ability of DCs to stimulate $\mathrm{T}$ cells in vitro by inducing their maturation and cytokine production. Interestingly, the ability of $\mathrm{NK}$ cells to promote $\mathrm{DC}$ activity may be lost during a chronic viral infection. In a three-cell in vitro system using NK cells, DCs, and liver epithelial cells, NK cells from healthy donors promoted DC expression of MHCII, CD40, and CD86 and improved $\mathrm{T}$ cell responses, while NK cells from chronically infected HCV patients were unable to improve DC function. ${ }^{211}$ This effect was dependent on signaling through the CD94/NKG2A inhibitory NK receptor complex and production of IL-10 and TGF- $\beta$ by NK cells. ${ }^{211}$

NK cells have also been shown to enhance the functional ability of DCs in vivo using mouse infection models, primarily through the production of IFN- $\gamma$. The effects of NK cells can be seen in DC recruitment to lymph nodes, cytokine production, and maturation. For example, NK cell production of IFN- $\gamma$ has been shown to modulate DC recruitment to lymph nodes during influenza infection in mice. ${ }^{152}$ Additionally, during a murine Chlamydia muridarum infection of the lung, NK cells strongly enhanced DC IL-12 production, which promoted T cell IFN- $\gamma$ production and a late reduction of the bacterial burden. ${ }^{212}$ The enhanced Th1 differentiation was dependent on NK cells and their ability to affect DCs through IFN- $\gamma$ production as well as NKG2D signaling. ${ }^{212} \mathrm{NK}$ cells are also capable of promoting DC maturation (MHC, CD40, CD80, CD86 upregulation) in vivo, which results in enhanced CD4+ $\mathrm{T}$ cell priming. ${ }^{213}$ However, this has only been seen during MCMV infection of mice deficient in IL-10, and detection of this process in wild-type animals has remained elusive. Nevertheless, the ability of NK cells to enhance $\mathrm{T}$ cell responses by promoting $\mathrm{DC}$ maturation, cytokine production, and recruitment has been detected both in vitro and in vivo.

An additional mechanism through which in vivo NK cell activity has been shown to improve $T$ cell responses is by positively influencing the number of DCs during MCMV infection. The Ly49H activating NK cell receptor is expressed by certain mouse strains (B6) but not others (Balb/c), and can directly 
interact with the $\mathrm{m} 157$ protein of MCMV..$^{71-73}$ This interaction leads to a significant expansion of NK cells expressing this receptor and contributes to the early control of virus replication. ${ }^{80,101} \mathrm{Balb} / \mathrm{c}$ mice are unable to control the virus early during infection and have a significant loss in the number of DCs, while B6 mice have lower virus titers and higher DC numbers. ${ }^{214}$ Similarly, in comparing WT Balb/c mice to $\mathrm{Balb} / \mathrm{c}$ mice congenic for the $\mathrm{B} 6 \mathrm{NK}$ cell locus that includes $\mathrm{Ly} 49 \mathrm{H},{ }^{215}$ the presence of NK cell-mediated virus control preserves the number of DCs during MCMV infection. ${ }^{216}$ The enhanced population of DCs was partially due to a reduction in IFN- $\alpha / \beta$ and led to improved CD8+ T cell responses early during the infection. ${ }^{216}$ Thus, NK cell activity can promote $\mathrm{T}$ cell responses by preserving DC populations via controlling the virus titer and limiting IFN- $\alpha / \beta$ production.

Some CD8+ T cell responses are heavily dependent on the presence of CD4+ T cells. For example, $\mathrm{CD} 8+\mathrm{T}$ cell responses against tumors, some vaccines, and some virus infections require CD4+ T cells. ${ }^{217-219}$ One mechanism of CD4 T cell help is through interactions with DCs that improve their ability to activate CD8+ $\mathrm{T}$ cells. ${ }^{220-222}$ Thus, there is a three-cell interaction (CD4-DC-CD8 T cell) that coordinates this response. However, there is some evidence that NK-DC interactions may substitute for CD4+ T cells in inducing antitumor CTL. ${ }^{223} \mathrm{In}$ this study, NK cells were activated by DCs to destroy A20 lymphoma cells. However, the activated NK cells expressed IFN $\gamma$ that primed DCs to express IL-12 and antigen to stimulate CD8+ T cells. ${ }^{223} \mathrm{In}$ other infection models, NK cells can enhance CD4independent $\mathrm{CD} 8+\mathrm{T}$ cell responses. For example, Toxoplasma gondii-infected CD4T cell-deficient mice show a protracted NK cell response due to continued IL-12 production. ${ }^{224} \mathrm{NK}$ cells in these mice express IFN $\gamma$ that is essential for priming of the T. gondiispecific CD8+ $\mathrm{T}$ cell response. ${ }^{224}$ In addition, CD8+ $\mathrm{T}$ cell responses to $\mathrm{HSV}$ are reduced in the absence of CD4+ T cells, and engrafting additional NK cells into these mice rescues this response. ${ }^{225}$ Thus, while these examples show evidence that NK cell-DC interactions can substitute for CD4+ T cell help to facilitate $\mathrm{CD} 8+\mathrm{T}$ cell responses, further studies of other model systems are needed to determine whether this is a generalizable mechanism.

\section{Negative Effects of NK Cells on DCs}

Despite having clear positive effects on DC functions in some circumstances, NK cells can also have negative effects by directly lysing DCs or decreasing their antigen presentation functions. ${ }^{226-229}$ In vitro experiments using human cells showed contact-dependent lysis of DCs by NK cells [Fig. 2(B)]. ${ }^{227,229}$ The primary targets of NK cells in these reports were immature DCs, as mature cells were protected from lysis in part due to inhibitory signaling from MHC-I. ${ }^{228}$ However, the direct lysis of mature DCs has also been detected via interactions of DC-expressed Nectin-2 and CD155 with the DNAM-1 receptor on NK cells (Table 4). ${ }^{230}$ Primary signaling through the NK cell activating receptor NKp30, which as mentioned above can also influence DC maturation, also contributes to the lysis of both mature and immature DCs. ${ }^{228,230}$ The differing outcomes of NKp30 ligation may be explained by alterations in the NK-DC ratio. Consistent with the effects of NK cells on DC maturation, changing the NK-DC ratio can also critically regulate the direct lysis of DCs, with a high NK-DC ratio favoring NK cellmediated elimination of DCs. ${ }^{206}$ Thus, under certain conditions NK cells can impact $\mathrm{T}$ cell responses in vitro through the lysis of DCs.

Despite the plethora of reports showing in vitro lysis of DCs by NK cells, the detection of this phenomenon in vivo has been somewhat more elusive. In one study, the ability of a DC-based vaccine to induce $\mathrm{CD} 8+\mathrm{T}$ cells was enhanced in mice depleted of NK cells. ${ }^{231}$ This negative effect of NK cells was mediated by TRAIL-dependent killing. ${ }^{231}$ The lysis of DCs has also been shown during MCMV infection. ${ }^{232}$ In this case, NK cells lysed infected DCs in a Ly49H-dependent fashion and eliminated the availability of DCs to promote sustained $\mathrm{T}$ cell activation. ${ }^{232}$ On the other hand, in a cancer model where mice were challenged using TS/A mammary adenocarcinoma tumor cells, NK cell lysis of DCs surprisingly improved the T cell 
A. NK cells promote dendritic cell antigen presentation to T cells

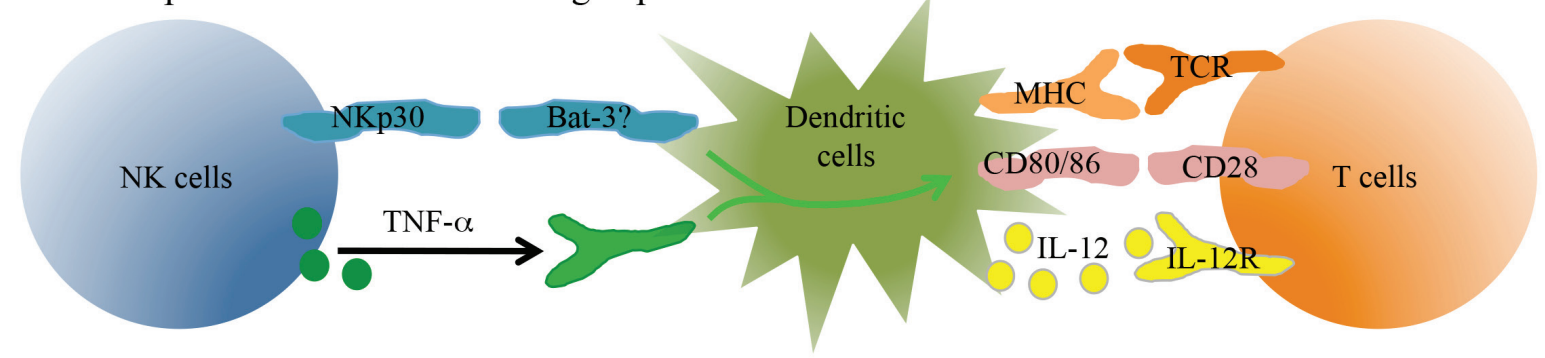

B. NK cells kill dendritic cells and reduce T cell stimulation

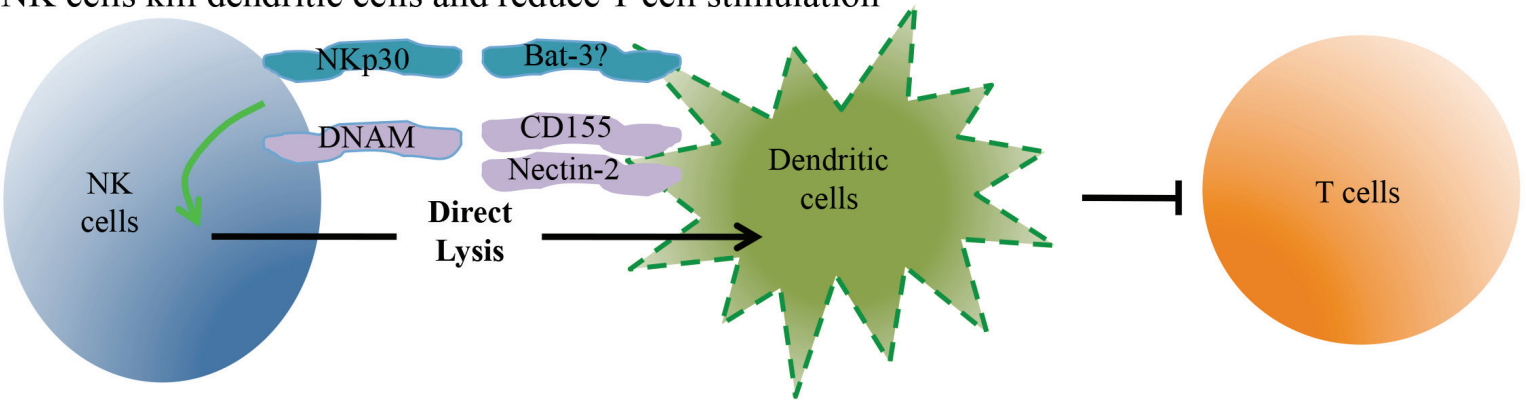

FIG. 2: NK cells influence dendritic cell activation and number. Dendritic cells play a central role in initiating T cell responses and subsequent $\mathrm{T}$ cell differentiation. NK cells directly interact with DCs through multiple interactions. (A) Activated NK cells express TNF and other cytokines that increase DC antigen processing and presentation to T cells. These signals also lead to greater amounts of co-stimulatory molecule expression and the secretion of pro-inflammatory cytokines by DCs that contribute to T cell differentiation. (B) NK cells can recognize cell-associated ligands and mediate cytolysis of immature DCs. The reduction in DC number limits T cell expansion during infection.

response as only immature DCs were removed and the more immunogenic DCs were selected. ${ }^{233}$ These mouse experiments show that NK cells are indeed capable of lysing DCs in vivo; however, further experiments are needed to understand the factors that regulate when this occurs and its outcomes on adaptive immune responses.

An additional effect observed is that NK cells can reduce the stimulatory capacity of DCs, which we showed using a mouse model of chronic infection with LCMV. ${ }^{119}$ Consistent with earlier reports, we found that the depletion of NK cells enhanced $\mathrm{T}$ cell responses during chronic but not acute strains of LCMV infection. ${ }^{119}$ These effects on T cells correlated with changes in the ability of APCs from NK cell-sufficient and -deficient mice to stimulate the proliferation of naïve antigen-specific $\mathrm{CD} 8+$ $\mathrm{T}$ cells. ${ }^{119}$ Despite the absence of changes in DC frequency or $\mathrm{MHC}$ and co-stimulatory molecule expression, NK cell depletion resulted in in vivoderived DCs with an enhanced capability of promoting proliferation of LCMV-specific CD8+ T cells in vitro. Importantly in the case of LCMV, the effect of NK cells on DCs is likely independent of any direct effects on virus replication. ${ }^{23}$ Though there has been one report showing a small localized effect of NK cells on early viral burden in the peritoneal cavity after i.p. infection with LCMV, ${ }^{35}$ our data and that of many others indicate that NK cell depletion has no measurable effect on early virus load during LCMV infection. Moreover, NK cell depletion did not alter viral control in SCID mice, which lack an adaptive immune system. ${ }^{234}$ Thus, through an as-yet undefined mechanism, NK cells negatively regulate the function of DCs to limit $\mathrm{T}$ cell responses. 


\section{E. NK Cells Modulate Antigen Availability to Impact T Cells}

In addition to directly affecting $\mathrm{T}$ cells and $\mathrm{DCs}$, NK cell activity can influence $\mathrm{T}$ cell responses simply by modulating the amount of antigen present. One of the first known functions of NK cells in host defense was the lysis of infected target cells to limit virus replication and spread. ${ }^{23} \mathrm{~T}$ cell responses are sensitive to changes in the amount of antigen and expression of co-stimulatory molecules and pro-inflammatory cytokines. ${ }^{235,236}$ At one end of the spectrum, T cells are tolerized at extremely low levels of antigen. ${ }^{237}$ At intermediate levels of antigen, there is a dose-dependent enhancement of $\mathrm{T}$ cell accumulation and function. When exposed to extremely high levels of antigen, $\mathrm{T}$ cell activity is reduced through several processes, including $\mathrm{T}$ cell exhaustion, $\mathrm{T}$ cell apoptosis, and T cell anergy. ${ }^{237-239}$ Therefore, the ability of NK cells to limit antigen levels can enhance or impede $\mathrm{T}$ cell responses depending on the situation. For example, infection of mice with the $\Delta \mathrm{m} 157$ strain of MCMV fails to activate $\mathrm{Ly} 49 \mathrm{H}+\mathrm{NK}$ cells, and the reduction in viral titer depends more upon CD8+ T cells. In this context, there is an enhanced CD8+ T cell expansion that is partially due to the increased antigen load in the absence of NK cell-mediated viral control. ${ }^{240}$ Thus, NK cell activity lowers the MCMV-specific T cell response in WT animals by reducing the presentation of MCMV epitopes and diminishing associated inflammatory signals. On the other hand, at higher viral inoculum doses the NK cell-mediated reduction in antigen levels can promote $\mathrm{T}$ cell responses. For example, NK cells have clear roles in reducing the MCMV burden at high doses of infection, ${ }^{241}$ which enhances the subsequent $\mathrm{T}$ cell response, perhaps by preventing $\mathrm{T}$ cells from being overwhelmed and undergoing functional exhaustion or deletion. Additionally, mouse susceptibility to lethal infection with mousepox increases with age, consistent with greatly reduced $\mathrm{T}$ cell responses in older animals. ${ }^{242}$ Interestingly, the reduced $\mathrm{T}$ cell response is not due to an intrinsic change in the ability of the $\mathrm{T}$ cells from aged mice to respond, but rather a defect in NK cell activation in aged mice. In younger animals, the NK cell response limits the viral dose to a level that promotes a vigorous $\mathrm{T}$ cells response, while the high level of virus in older mice, where NK cells are less effective, overwhelms the ability of the $\mathrm{T}$ cells to respond. Therefore, depending on the initial amount of antigen present, the ability of antiviral activity of NK cells can have stimulatory or inhibitory functions on the $\mathrm{T}$ cell response.

The two examples above involve NK cell-mediated reduction in antigen, which can have differing effects on T cells depending on the infection. However, NK cell cytolytic activity can lead to the release of more antigen to better stimulate $\mathrm{T}$ cell responses. This is seen in a model where mice are given targets that express OVA but lack the MHC-I molecule $\mathrm{K}^{\mathrm{b}}$. In this scenario, the donor cells are killed by NK cells due to the absence of $\mathrm{K}^{\mathrm{b}}$. This NK cell-mediated killing of target cells releases OVA protein, resulting in a vigorous OVA-specific CD8+ $\mathrm{T}$ cell response. ${ }^{243}$ If the antigen-loaded target cells express MHC-I, then there is minimal lysis of the cells and a greatly reduced CD8+ T cell response. ${ }^{243,244}$ Taken together, these data show that NK cell lysis of target cells can indirectly influence the subsequent $\mathrm{T}$ cell response by altering antigen levels, though this phenomenon can have a positive or negative effect on $\mathrm{T}$ cells depending on the amount of antigen and the inflammatory context.

\section{F. T Cell Regulation of NK Cells}

The interaction of NK cells with T cells is a "two-way street" and these interactions can inhibit or enhance NK cell functions. Treg cells limit NK cells through two mechanisms. One involves Treg expression of TGF- $\beta$ to inhibit NK cells, ${ }^{245}$ and there is evidence that Treg cells and TGF- $\beta$ regulate murine NK cells during MCMV infection. ${ }^{246}$ Another mechanism is related to Treg cell expression of higher amounts of CD25, a component of the IL-2R, than is expressed by NK cells. Thus, Treg cells compete for IL-2 and starve NK cells of this important growth factor. ${ }^{247}$ Immature CD127+ NK cells upregulate IL-2R when activated by IL-12, thereby permitting subsequent exposure to IL-2 to further induce these immature NK cells to transition into mature NK cells. ${ }^{127}$ IL-2 signaling into NK cells boosts their ability to 
respond to weak stimuli, and this is enhanced by the depletion of Treg cells. ${ }^{248}$ In support of this mechanism, a recent study showed that Treg cells reduce the bioavailability of IL-2 in the pancreatic islets to inhibit NK cell proliferation and expression of IFN $\gamma$, thus protecting against NK cell contributions to the diabetogenic process. ${ }^{249}$ Thus, therapies that manipulate IL-2 levels can affect NK cells directly or by modulating Treg activity.

Memory CD4+ T cells can also enhance NK cell functions after infection. It has been proposed that one of the main functions of IL-2 made by activated memory $\mathrm{T}$ cells within the first hours of infection may be to initiate NK cell responses. For example, memory CD4+ $\mathrm{T}$ cells that are induced after Pneumocystis murina infection act during reinfection to improve NK cell-mediated activity against the pathogen. ${ }^{250}$ Furthermore, CD4+ T cells produce IL-2 that activates NK cells to make IFN $\gamma$ during Plasmodium falciparum infection and primed CD4+ $\mathrm{T}$ cells are needed to induce or maintain NK cell responses against Leishmania major infection. ${ }^{251,252}$ In a rhesus macaque model, there is evidence of cooperation between central memory CD4+ T cells and NK cells. ${ }^{253} \mathrm{NK}$ cell effector functions are maintained in macaques that are "controllers" whereas "non-controllers" show diminished NK cell activity. In vitro evidence in this model suggests that SIVGAG-specific memory CD4 T cells produce IL-2 to prime NK cells functions. ${ }^{253}$ Similar findings are seen when circulating NK cells and memory T cells are examined in rabies-vaccinated people. ${ }^{254} \mathrm{NK}$ cells show sustained cytokine production and degranulation when co-cultured with memory $\mathrm{T}$ cells that are stimulated to make IL-2 by inactivated rabies virus. ${ }^{254}$ In contrast, NK cells are not activated when mixed with $\mathrm{T}$ cells from unvaccinated individuals, who do not make IL-2 in response to rabies antigen. Memory T cell expression of IL-2 is implicated in these studies, but further studies are needed to determine how memory cell expression of IFN $\gamma$ and other cytokines affects early NK cell responses. Currently, no studies have explored the interplay between memory $\mathrm{T}$ cells and memory NK cells.

\section{NK CELLS AFFECT HUMORAL IMMUNITY}

In addition to their effects on $\mathrm{T}$ cells, $\mathrm{NK}$ cells directly and indirectly influence B cell responses as well. These interactions are complex and can be beneficial or detrimental depending on the model system. For example, cloned mouse NK cells can recognize and kill B cells. ${ }^{255}$ Likewise, in vivo induction of NK cells with poly(I:C) leads to reduced antibody responses to phosphorylcholine of R36a pneumococcal vaccine or sheep red blood cells. ${ }^{256}$ Other data show that human NK cells can kill B cells depending on the activation state of the $\mathrm{B}$ cells. ${ }^{257}$ However, there is evidence that NK cells inhibit B cells indirectly by killing essential dendritic cell populations that are needed to sustain the B cell response. ${ }^{256,258}$ In contrast to those findings, other data show that activated NK cells can promote B cell responses. ${ }^{259}$ NK cells release IFN $\gamma$ that drives class switching in $B$ cells and stimulates B cell proliferation. NK cells can also stimulate $\operatorname{IgG}$ class switching in B cells through cell-cell contact in vitro, ${ }^{260}$ while in vivo NK cell depletion reduces antibody responses to Brucella abortus infection in mice. ${ }^{261}$ Additionally, NK cells can increase antigen presentation by B cells through direct cell-cell contact, ${ }^{262}$ which likely improves their interaction with CD4+ T cells. The role of NK cells in humoral immune responses to virus infection is not well explored.

In the LCMV model, CD4+ T follicular helper cells $\left(\mathrm{T}_{\mathrm{FH}}\right)$ cells that enter the $\mathrm{B}$ cell follicle are needed to induce antibody responses. ${ }^{263-265} \mathrm{We}$ observed that primary LCMV-specific CD4+ $\mathrm{T}$ cells were increased in NK cell-depleted mice compared to the NK cell-replete mice. ${ }^{119,188}$ If NK cells specifically target $\mathrm{CD} 4+\mathrm{T}_{\mathrm{FH}}$ cells, then there will likely be reductions in CD4 T cell-dependent humoral immune responses, including germinal center reactions and the development of memory $\mathrm{B}$ cells and plasma cells. CD4+ $\mathrm{T}_{\mathrm{FH}}$ cells begin to form by day 3 of infection. ${ }^{266}$ Thus, early NK cell elimination of activated CD4+ T cells might result in lower antibody levels or poor recall responses long-term. Further studies are needed to determine whether NK cell depletion leads to a sustained 
CD4+ $\mathrm{T}$ cell response or changes in Th1 versus $\mathrm{T}_{\mathrm{FH}}$ lineage commitment, or increases antibody levels. Such information is relevant to vaccine design, since vaccines stimulate $C D 4+T$ cells and $B$ cells and most vaccines are evaluated based on their induction of antibody.

\section{CONCLUSIONS}

The immediate early functions of NK cells during infection are well established. There are continuing efforts to identify factors that regulate or activate NK cells. Recent studies demonstrate that NK cells affect adaptive immune responses. Additionally, it is now appreciated that NK cells persist for far longer than previously appreciated. NK cells also show aberrant phenotypes in the context of persisting virus infections. In light of these new findings, there are new questions that should be addressed.

NK cells can be activated through multiple pathways, but we do not know whether these distinct signaling events lead to distinguishable NK cell phenotypes. For example, are certain interferons or cytokines needed for NK cell regulation of adaptive immune responses, or does the engagement of activating receptors accomplish the same function? What activation pathways result in long-lived or short-lived NK cell populations? Memory NK cells can protect against $\mathrm{CMV}$ infection, but it remains to be seen whether memory NK cells are beneficial or harmful to memory $\mathrm{T}$ cell responses in other models. While the ability of NK cells to regulate $\mathrm{T}$ cell responses to protect against immune-mediated pathology has recently been described, NK cells can also contribute to pathogenesis. For example, NK cells contribute to the lung pathology induced by influenza infection in mice. ${ }^{267}$ The pathogenesis of infection was diminished when NK cells were depleted with antibodies and adoptive transfer of activated NK cells into influenza-infected mice worsened disease in the recipients. ${ }^{267}$ Further experiments are needed to understand the contributions of NK cells toward pathogenesis as well as the potential role of memory NK cells in viral pathogenesis.

Antigen-specific $T$ cells lose functionality dur- ing persisting virus infection and cancer, in part due to $\mathrm{T}$ cell expression of inhibitory receptors. There is considerable interest in targeting these immunoregulatory pathways by treating patients with antibodies that interfere with ligand-receptor interactions. However, NK cells express many of these receptors, including LAG-3, PD-1, and TIGIT. These receptors are induced on NK cells by cytokines such as IL-10, IL-12, TGF- $\beta$, and interferons that are expressed during chronic infection and in the tumor environment. ${ }^{268}$ These data raise the specter that blockading these interactions to revive exhausted CD8+ $\mathrm{T}$ cell responses may also increase NK cell responses, which could be detrimental to immune control of antiviral or antitumor immunity. NK cells resist tumor growth and are engaged in several antitumor therapies where antibody-directed NK cells kill tumor cells. Now that it is clear that NK cells affect $\mathrm{T}$ cell responses, there is the dire possibility that the immediate benefits of NK cell-inducing therapies are countered by the detrimental long-term effects of NK cell activation on tumor-specific T cell exhaustion. Thus, there is a need to better understand the interplay between NK cells and other protective wings of the immune system.

\section{ACKNOWLEDGMENTS}

This work was supported by NIH R01 AI074862 to J.K.W., NIH T32 AI007273 to K.D.C., and an Ellison Medical Foundation New Scholar Award to S.N.W., as well as institutional startup funds from the University of North Carolina School of Medicine to J.K.W.

\section{REFERENCES}

1. Vivier E, Tomasello E, Baratin M, Walzer T, Ugolini S. Functions of natural killer cells. Nat Immunol. 2008;9:503-10.

2. Vivier E, Ugolini S, Blaise D, Chabannon C, Brossay L. Targeting natural killer cells and natural killer T cells in cancer. Nat Rev Immunol. 2012;12:239-52.

3. Sun JC, Lanier LL. NK cell development, homeostasis and function: parallels with CD8 T cells. Nat Rev Immunol. 2011;11:645-57. 
4. Lanier LL. Evolutionary struggles between NK cells and viruses. Nat Rev Immunol. 2008;8:259-68.

5. Biron CA, Nguyen KB, Pien GC, Cousens LP, SalazarMather TP. Natural killer cells in antiviral defense: function and regulation by innate cytokines. Annu Rev Immunol. 1999;17:189-220.

6. Lanier LL. Up on the tightrope: natural killer cell activation and inhibition. Nat Immunol.2008;9:495-502.

7. Huntington ND, Vosshenrich CA, Di Santo JP. Developmental pathways that generate natural-killercell diversity in mice and humans. Nat Rev Immunol. 2007;7:703-14.

8. Kumar V,Ben-Ezra J, Bennett M, Sonnenfeld G. Natural killer cells in mice treated with 89strontium: normal target-binding cell numbers but inability to kill even after interferon administration. J Immunol. 1979;123:1832-8.

9. Seaman WE, Blackman MA, Gindhart TD, Roubinian JR, Loeb JM, Talal N. beta-Estradiol reduces natural killer cells in mice. J Immunol. 1978;121:2193-8.

10. Di Santo JP. Functionally distinct NK-cell subsets: developmental origins and biological implications. Eur J Immunol. 2008;38:2948-51.

11. Horowitz A, Strauss-Albee DM,Leipold M,KuboJ,NematGorgani N, Dogan OC, Dekker CL, Mackey S, Maecker H, Swan GE, Davis MM, Norman PJ, Guethlein LA, Desai M, Parham P, Blish CA. Genetic and environmental determinants of human NK cell diversity revealed by mass cytometry. Sci Transl Med. 2013;5:208ra145.

12. Shi FD, Ljunggren HG, La Cava A, Van Kaer L. Organspecific features of natural killer cells. Nat Rev Immunol. 2011;11:658-71.

13. Guo H,Topham DJ. Interleukin-22 (IL-22) production by pulmonary natural killer cells and the potential role of IL-22 during primary influenza virus infection. J Virol. 2010;84:7750-9.

14. Small CL, McCormick S, Gill N, Kugathasan K, Santosuosso M, Donaldson N, Heinrichs DE, Ashkar A, Xing Z. NK cells play a critical protective role in host defense against acute extracellular Staphylococcus aureus bacterial infection in the lung. J Immunol. 2008;180:5558-68.

15. Cella M, Fuchs A, Vermi W, Facchetti F, Otero K, Lennerz JK, Doherty JM, Mills JC, Colonna M. A human natural killer cell subset provides an innate source of IL-22 for mucosal immunity. Nature. 2009;457:722-5.

16. Herberman RB, Nunn ME, Holden HT, Lavrin DH. Natural cytotoxic reactivity of mouse lymphoid cells against syngeneic and allogeneic tumors. II. Characterization of effector cells. Int J Cancer J Int Cancer. 1975;16:230-9.

17. Kiessling R, Klein E, Pross H, Wigzell H. "Natural"killer cells in the mouse. II. Cytotoxic cells with specificity for mouse Moloney leukemia cells. Characteristics of the killer cell. Eur J Immunol. 1975;5:117-21.
18. Gidlund M, Orn A, Wigzell H, Senik A, Gresser I. Enhanced NK cell activity in mice injected with interferon and interferon inducers. Nature. 1978;273:759-61.

19. Trinchieri G, Santoli D. Anti-viral activity induced by culturing lymphocytes with tumor-derived or virustransformed cells. Enhancement of human natural killer cell activity by interferon and antagonistic inhibition of susceptibility of target cells to lysis. J Exp Med. 1978;147:1314-33.

20. Welsh RM Jr. Cytotoxic cells induced during lymphocytic choriomeningitis virus infection of mice. I. Characterization of natural killer cell induction. J Exp Med. 1978;148:163-81.

21. Quinnan GV,Manischewitz JE. The role of natural killer cells and antibody-dependent cell-mediated cytotoxicity during murine cytomegalovirus infection. J Exp Med. 1979;150:1549-54.

22. Welsh RM Jr, Zinkernagel RM. Heterospecific cytotoxic cell activity induced during the first three days of acute lymphocytic choriomeningitis virus infection in mice. Nature. 1977;268:646-8.

23. Bukowski JF, Woda BA, Habu S, Okumura K, Welsh RM. Natural killer cell depletion enhances virus synthesis and virus-induced hepatitis in vivo. J Immunol. 1983;131:1531-8.

24. Burshtyn DN. NK cells and poxvirus infection. Front Immunol. 2013;4:7.

25. Jacoby RO, Bhatt PN, Brownstein DG. Evidence that NK cells and interferon are required for genetic resistance to lethal infection with ectromelia virus. Arch Virol. 1989;108:49-58.

26. Orange JS. Natural killer cell deficiency. J Allergy Clin Immunol. 2013;132:515-25.

27. Biron CA, Byron KS, Sullivan JL. Severe herpesvirus infections in an adolescent without natural killer cells. New Engl J Med. 1989;320:1731-5.

28. Lee SH, Biron CA. Here today - not gone tomorrow: roles for activating receptors in sustaining NK cells during viral infections. Eur J Immunol. 2010;40:923-32.

29. Khakoo SI, Thio CL, Martin MP, Brooks CR, Gao $\mathrm{X}$, Astemborski J, Cheng J, Goedert JJ, Vlahov D, Hilgartner M, Cox S, Little AM, Alexander GJ, Cramp ME, O’Brien SJ, Rosenberg WM, Thomas DL, Carrington M. HLA and NK cell inhibitory receptor genes in resolving hepatitis $\mathrm{C}$ virus infection. Science. 2004;305:872-4.

30. Martin MP, Gao X, Lee JH, Nelson GW, Detels R, Goedert JJ, Buchbinder S, Hoots K, Vlahov D, Trowsdale J, Wilson M, O'Brien SJ, Carrington M. Epistatic interaction between KIR3DS1 and HLA-B delays the progression to AIDS. Nat Genet. 2002;31:429-34.

31. Martin MP, Qi Y, Gao X, Yamada E, Martin JN, Pereyra F, Colombo S, Brown EE, Shupert WL, Phair J, Goedert JJ, Buchbinder S, Kirk GD, Telenti A, Connors M, 
O'Brien SJ, Walker BD, Parham P, Deeks SG, McVicar DW, Carrington M. Innate partnership of HLA-B and KIR3DL1 subtypes against HIV-1. Nat Genet. 2007;39:733-40.

32. Lanier LL. NK cell recognition. Annu Rev Immunol. 2005;23:225-74.

33. Kim S, Poursine-Laurent J, Truscott SM, Lybarger L, Song YJ, Yang L, French AR, Sunwoo JB, Lemieux S, Hansen TH, Yokoyama WM. Licensing of natural killer cells by host major histocompatibility complex class I molecules. Nature. 2005;436:709-13.

34. Orange JS. Formation and function of the lytic NK-cell immunological synapse. Nat Rev Immunol. 2008;8:713-25.

35. Mack EA, Kallal LE, Demers DA, Biron CA. Type 1 interferon induction of natural killer cell gamma interferon production for defense during lymphocytic choriomeningitis virus infection. mBio. 2011;2.

36. Orange JS, Biron CA. Characterization of early IL-12, IFN-alphabeta, and TNF effects on antiviral state and NK cell responses during murine cytomegalovirus infection. J Immunol. 1996;156:4746-56.

37. Hwang I, Scott JM, Kakarla T, Duriancik DM, Choi S, Cho C, Lee T, Park H, French AR, Beli E, Gardner E, Kim S. Activation mechanisms of natural killer cells during influenza virus infection. PloS One. 2012;7:e51858.

38. Vosshenrich CA, Ranson T, Samson SI, Corcuff E, Colucci F, Rosmaraki EE, Di Santo JP. Roles for common cytokine receptor gamma-chain-dependent cytokines in the generation, differentiation, and maturation of NK cell precursors and peripheral NK cells in vivo. J Immunol. 2005;174:1213-21.

39. Carson WE, Giri JG, Lindemann MJ, Linett ML, Ahdieh M, Paxton R, Anderson D, Eisenmann J, Grabstein K, Caligiuri MA. Interleukin (IL) 15 is a novel cytokine that activates human natural killer cells via components of the IL-2 receptor. J Exp Med. 1994;180:1395-403.

40. Chan SH, Perussia B, Gupta JW, Kobayashi M, Pospisil M, Young HA, Wolf SF, Young D, Clark SC, Trinchieri G.Induction of interferon gamma production by natural killer cell stimulatory factor: characterization of the responder cells and synergy with other inducers. J Exp Med. 1991;173:869-79.

41. Henney CS, Kuribayashi K, Kern DE, Gillis S. Interleukin-2 augments natural killer cell activity. Nature. 1981;291:335-8.

42. Park SY, Saijo K, Takahashi T, Osawa M, Arase H, Hirayama N, Miyake K, Nakauchi H, Shirasawa T, Saito T. Developmental defects of lymphoid cells in Jak3 kinase-deficient mice. Immunity. 1995;3:771-82.

43. Wolf SF, Temple PA, Kobayashi M, Young D, Dicig M, Lowe L, Dzialo R, Fitz L, Ferenz C, Hewick RM,
Kelleher K, Herrmann SH, Clark SC, Azzoni L, Chan $\mathrm{SH}$, Trinchieri G, Perussia B. Cloning of cDNA for natural killer cell stimulatory factor, a heterodimeric cytokine with multiple biologic effects on $\mathrm{T}$ and natural killer cells. J Immunol. 1991;146:3074-81.

44. Chaix J, Tessmer MS, Hoebe K, Fuseri N, Ryffel B, Dalod M, Alexopoulou L, Beutler B, Brossay L, Vivier E, Walzer T. Cutting edge: Priming of NK cells by IL18. J Immunol. 2008;181:1627-31.

45. Suzuki N, Chen NJ, Millar DG, Suzuki S, Horacek T, Hara H, Bouchard D, Nakanishi K, Penninger JM, Ohashi PS, Yeh WC. IL-1 receptor-associated kinase 4 is essential for IL-18-mediated NK and Th1 cell responses. J Immunol. 2003;170:4031-5.

46. Takeda K, Tsutsui H, Yoshimoto T, Adachi O, Yoshida N, Kishimoto T, Okamura H, Nakanishi K, Akira S. Defective NK cell activity and Th1 response in IL-18deficient mice. Immunity. 1998;8:383-90.

47. Okamura H, Tsutsi H, Komatsu T, Yutsudo M, Hakura A, Tanimoto T, Torigoe K, Okura T, Nukada Y, Hattori K, Akita K, Namba M, Tanabe F, Konishi $90 \quad 0$ ‘/b nnnnnK, Fukuda S, Kurimoto M. Clon-ing of a new cytokine that induces IFN-gamma production by $\mathrm{T}$ cells. Nature. 1995;378:88-91.

48. Pien GC, Satoskar AR, Takeda K, Akira S, Biron CA. Cutting edge: selective IL-18 requirements for induction of compartmental IFN-gamma responses during viral infection. J Immunol. 2000;165:4787-91.

49. Lauwerys BR, Renauld JC, Houssiau FA. Synergistic proliferation and activation of natural killer cells by interleukin 12 and interleukin 18. Cytokine.1999;11:822-30.

50. Nguyen KB, Salazar-MatherTP, Dalod MY, Van Deusen JB, Wei XQ, Liew FY, Caligiuri MA, Durbin JE, Biron CA. Coordinated and distinct roles for IFN-alpha beta, IL-12, and IL-15 regulation of NK cell responses to viral infection. J Immunol. 2002;169:4279-87.

51. Ye J, Ortaldo JR, Conlon K, Winkler-Pickett R, Young HA. Cellular and molecular mechanisms of IFN-gamma production induced by IL-2 and IL-12 in a human NK cell line. J Leukocyte Biol. 1995;58:225-33.

52. Humann J, Lenz LL. Activation of naive NK cells in response to Listeria monocytogenes requires IL-18 and contact with infected dendritic cells. J Immunol. 2010;184:5172-8.

53. Schmidt RL, Filak HC, Lemon JD, Potter TA, Lenz LL. A LysM and SH3-domain containing region of the Listeria monocytogenes p60 protein stimulates accessory cells to promote activation of host NK cells. PLoS Pathogens. 2011;7:e1002368.

54. Humann J, Bjordahl R, Andreasen K, Lenz LL. Expression of the p60 autolysin enhances NK cell activation and is required for listeria monocytogenes expansion in IFN-gamma-responsive mice. J Immunol. 2007;178:2407-14. 
55. Trinchieri G. Type I interferon: friend or foe? J Exp Med. 2010;207:2053-63.

56. Biassoni R. Natural killer cell receptors. Adv Exp Med Biol. 2008;640:35-52.

57. Pessino A, Sivori S, Bottino C, Malaspina A, Morelli L, Moretta L, Biassoni R, Moretta A. Molecular cloning of NKp46: a novel member of the immunoglobulin superfamily involved in triggering of natural cytotoxicity. J Exp Med. 1998;188:953-60.

58. Sivori S, Vitale M, Morelli L, Sanseverino L, Augugliaro R, Bottino C,Moretta L, Moretta A.p46, a novel natural killer cell-specific surface molecule that mediates cell activation. J Exp Med. 1997;186:1129-36.

59. Vitale M, Bottino C, Sivori S, Sanseverino L, Castriconi R, Marcenaro E, Augugliaro R, Moretta L, Moretta A. NKp44, a novel triggering surface molecule specifically expressed by activated natural killer cells, is involved in non-major histocompatibility complex-restricted tumor cell lysis. J Exp Med. 1998;187:2065-72.

60. Pende D, Parolini S, Pessino A, Sivori S, Augugliaro R, Morelli L,Marcenaro E, Accame L, Malaspina A, Biassoni R, Bottino C, Moretta L, Moretta A. Identification and molecular characterization of NKp30, a novel triggering receptor involved in natural cytotoxicity mediated by human natural killer cells. J Exp Med. 1999;190:1505-16.

61. Bauer S, Groh V, Wu J, Steinle A, Phillips JH, Lanier LL, Spies T. Activation of NK cells and T cells by NKG2D, a receptor for stress-inducible MICA. Science. 1999;285:727-9.

62. Wu J, Song Y, Bakker AB, Bauer S, Spies T, Lanier LL, Phillips JH. An activating immunoreceptor complex formed by NKG2D and DAP10. Science. 1999;285:730-2.

63. Campbell KS, Hasegawa J. Natural killer cell biology: An update and future directions. J Allergy Clin Immunol. 2013;132:536-44.

64. Fortin C, Huang X, Yang Y. Both NK cell-intrinsic and -extrinsic STAT1 signaling are required for NK cell response against vaccinia virus.J Immunol.2013;191:363-8.

65. Miyagi T, Gil MP, Wang X, Louten J, Chu WM, Biron CA. High basal STAT4 balanced by STAT1 induction to control type 1 interferon effects in natural killer cells. J Exp Med. 2007;204:2383-96.

66. Zawislak CL, Beaulieu AM, Loeb GB, Karo J, Canner D, Bezman NA, Lanier LL, Rudensky AY, Sun JC. Stagespecific regulation of natural killer cell homeostasis and response against viral infection by microRNA-155. Proc Natl Acad Sci U S A. 2013;110:6967-72.

67. Leong JW, Sullivan RP, Fehniger TA. Natural killer cell regulation by microRNAs in health and disease.J Biomed Biotechnol. 2012;2012:632329.

68. Sullivan RP, Leong JW, Fehniger TA. MicroRNA regulation of natural killer cells. Front Immunol. 2013;4:44.
69. Sullivan RP, Leong JW, Schneider SE, Keppel CR, Germino E, French AR, Fehniger TA. MicroRNAdeficient NK cells exhibit decreased survival but enhanced function. J Immunol. 2012;188:3019-30.

70. Beaulieu AM, Bezman NA, Lee JE, Matloubian M, Sun JC, Lanier LL. MicroRNA function in NK-cell biology. Immunol Rev. 2013;253:40-52.

71. Brown MG, Dokun AO, Heusel JW, Smith HR, Beckman DL, Blattenberger EA, Dubbelde CE, Stone LR, Scalzo AA, Yokoyama WM. Vital involvement of a natural killer cell activation receptor in resistance to viral infection. Science. 2001;292:934-7.

72. Daniels KA, Devora G, Lai WC, O’Donnell CL, Bennett $\mathrm{M}$, Welsh RM. Murine cytomegalovirus is regulated by a discrete subset of natural killer cells reactive with monoclonal antibody to Ly49H. J Exp Med. 2001;194:29-44.

73. Lee SH, Girard S, Macina D, Busa M, Zafer A, Belouchi A, Gros P, Vidal SM. Susceptibility to mouse cytomegalovirus is associated with deletion of an activating natural killer cell receptor of the C-type lectin superfamily. Nat Genet. 2001;28:42-5.

74. Voigt V, Forbes CA, Tonkin JN, Degli-Esposti MA, Smith HR, Yokoyama WM, Scalzo AA. Murine cytomegalovirus $\mathrm{m} 157$ mutation and variation leads to immune evasion of natural killer cells. Proc Natl Acad Sci U S A. 2003;100:13483-8.

75. Desrosiers MP, Kielczewska A, Loredo-Osti JC, Adam SG, Makrigiannis AP, Lemieux S, Pham T, Lodoen MB, Morgan K, Lanier LL, Vidal SM. Epistasis between mouse Klra and major histocompatibility complex class I loci is associated with a new mechanism of natural killer cell-mediated innate resistance to cytomegalovirus infection. Nat Genet. 2005;37:593-9.

76. Mandelboim O, Lieberman N, Lev M, Paul L, Arnon TI, Bushkin Y, Davis DM, Strominger JL, Yewdell JW, Porgador A. Recognition of haemagglutinins on virusinfected cells by NKp46 activates lysis by human NK cells. Nature. 2001;409:1055-60.

77. Arnon TI, Lev M, Katz G, Chernobrov Y, Porgador A, Mandelboim O. Recognition of viral hemagglutinins by NKp44 but not by NKp30. Eur J Immunol. 2001;31:2680-9.

78. Jarahian M, Watzl C, Fournier P, Arnold A, Djandji D, Zahedi S, Cerwenka A, Paschen A, Schirrmacher V, Momburg F. Activation of natural killer cells by newcastle disease virus hemagglutinin-neuraminidase. J Virol. 2009;83:8108-21.

79. Hershkovitz O, Rosental B, Rosenberg LA, NavarroSanchez ME, Jivov S, Zilka A, Gershoni-Yahalom O, Brient-Litzler E, Bedouelle H, Ho JW, Campbell KS, Rager-Zisman B, Despres P, Porgador A. NKp44 receptor mediates interaction of the envelope glycoproteins from the West Nile and Dengue viruses with NK cells. J Immunol. 2009;183:2610-21. 
80. Arase H, Mocarski ES, Campbell AE, Hill AB, Lanier LL. Direct recognition of cytomegalovirus by activating and inhibitory NK cell receptors. Science. 2002;296:1323-6.

81. Dunn C, Chalupny NJ, Sutherland CL, Dosch S, Sivakumar PV, Johnson DC, Cosman D. Human cytomegalovirus glycoprotein UL16 causes intracellular sequestration of NKG2D ligands, protecting against natural killer cell cytotoxicity. J Exp Med. 2003;197:1427-39.

82. Beck S, Barrell BG. Human cytomegalovirus encodes a glycoprotein homologous to MHC class-I antigens. Nature. 1988;331:269-72.

83. Thomas M, Boname JM, Field S, Nejentsev S, Salio M, Cerundolo V, Wills M, Lehner PJ. Down-regulation of NKG2D and NKp80 ligands by Kaposi's sarcomaassociated herpesvirus K5 protects against NK cell cytotoxicity. Proc Natl Acad Sci U S A. 2008;105:1656-61.

84. Cohen GB, Gandhi RT, Davis DM, Mandelboim O, Chen BK, Strominger JL, Baltimore D. The selective downregulation of class I major histocompatibility complex proteins by HIV-1 protects HIV-infected cells from NK cells. Immunity. 1999;10:661-71.

85. Bonaparte MI, Barker E. Killing of human immunodeficiency virus-infected primary $\mathrm{T}$-cell blasts by autologous natural killer cells is dependent on the ability of the virus to alter the expression of major histocompatibility complex class I molecules. Blood. 2004;104:2087-94.

86. Shah AH, Sowrirajan B, Davis ZB, Ward JP, Campbell EM, Planelles V, Barker E. Degranulation of natural killer cells following interaction with HIV-1-infected cells is hindered by downmodulation of NTB-A by Vpu. Cell Host Microbe. 2010;8:397-409.

87. Ward J, Bonaparte M, Sacks J, Guterman J, Fogli M, Mavilio D, Barker E. HIV modulates the expression of ligands important in triggering natural killer cell cytotoxic responses on infected primary T-cell blasts. Blood. 2007;110:1207-14.

88. Arnon TI, Achdout H, Levi O, Markel G, Saleh N, Katz G, Gazit R, Gonen-Gross T, Hanna J, Nahari E, Porgador A, Honigman A, Plachter B, Mevorach D, Wolf DG, Mandelboim O. Inhibition of the NKp30 activating receptor by pp65 of human cytomegalovirus. Nat Immunol. 2005;6:515-23.

89. Corado J, Toro F, Rivera H, Bianco NE, Deibis L, De Sanctis JB. Impairment of natural killer (NK) cytotoxic activity in hepatitis $\mathrm{C}$ virus (HCV) infection. Clin Exp Immunol. 1997;109:451-7.

90. Holder KA, Stapleton SN, Gallant ME, Russell RS, Grant MD. Hepatitis $\mathrm{C}$ virus-infected cells downregulate NKp30 and inhibit ex vivo NK cell functions. J Immunol. 2013;191:3308-18.

91. Crotta S, Stilla A, Wack A, D'Andrea A, Nuti S, D’Oro U, Mosca M, Filliponi F, Brunetto RM, Bonino F,
Abrignani S, Valiante NM. Inhibition of natural killer cells through engagement of CD81 by the major hepatitis C virus envelope protein. J Exp Med. 2002;195:35-41.

92. Tseng CT, Klimpel GR. Binding of the hepatitis $\mathrm{C}$ virus envelope protein $\mathrm{E} 2$ to $\mathrm{CD} 81$ inhibits natural killer cell functions. J Exp Med. 2002;195:43-9.

93. Nattermann J, Nischalke HD, Hofmeister V, Ahlenstiel G, Zimmermann H, Leifeld L, Weiss EH, Sauerbruch T, Spengler U. The HLA-A2 restricted T cell epitope HCV core 35-44 stabilizes HLA-E expression and inhibits cytolysis mediated by natural killer cells. Am J Pathol. 2005;166:443-53.

94. Born TL, Morrison LA, Esteban DJ, VandenBos T, Thebeau LG, Chen N, Spriggs MK, Sims JE, Buller RM. A poxvirus protein that binds to and inactivates IL-18, and inhibits NK cell response. J Immunol. 2000;164:3246-54.

95. Kotenko SV, Saccani S, Izotova LS, Mirochnitchenko OV, Pestka S. Human cytomegalovirus harbors its own unique IL-10 homolog (cmvIL-10). Proc Natl Acad Sci U S A. 2000;97:1695-700.

96. Moore KW, Vieira P, Fiorentino DF, Trounstine ML, Khan TA, Mosmann TR. Homology of cytokine synthesis inhibitory factor (IL-10) to the Epstein-Barr virus gene BCRFI. Science. 1990;248:1230-4.

97. Xiang Y, Moss B. IL-18 binding and inhibition of interferon gamma induction by human poxvirus-encoded proteins. Proc Natl Acad Sci U S A. 1999;96:11537-42.

98. Jonjic S, Babic M, Polic B, Krmpotic A. Immune evasion of natural killer cells by viruses. Curr Opin Immunol. 2008;20:30-8.

99. Orange JS, Fassett MS, Koopman LA, Boyson JE, Strominger JL. Viral evasion of natural killer cells. Nat Immunol. 2002;3:1006-12.

100. Robbins SH, Tessmer MS, Mikayama T, Brossay L. Expansion and contraction of the NK cell compartment in response to murine cytomegalovirus infection. J Immunol. 2004;173:259-66.

101. Dokun AO, Kim S, Smith HR, Kang HS, Chu DT, Yokoyama WM. Specific and nonspecific NK cell activation during virus infection. Nat Immunol. 2001;2:951-6.

102. Sun JC, Lopez-Verges S, Kim CC, DeRisi JL, Lanier LL. NK cells and immune "memory". J Immunol. 2011;186:1891-7.

103. Sun JC, Beilke JN, Lanier LL. Adaptive immune features of natural killer cells. Nature. 2009;457:557-61.

104. Beziat V, Liu LL, Malmberg JA, Ivarsson MA, Sohlberg E, Bjorklund AT, Retiere C, Sverremark-Ekstrom E, Traherne J, Ljungman P, Schaffer M, Price DA, Trowsdale J, Michaelsson J, Ljunggren HG, Malmberg KJ. NK cell responses to cytomegalovirus infection lead to stable imprints in the human KIR repertoire and involve activating KIRs. Blood. 2013;121:2678-88. 
105. Zhang T, Scott JM, Hwang I, Kim S. Cutting edge: antibody-dependent memory-like NK cells distinguished by FcRgamma deficiency. Journal of Immunology. 2013;190:1402-6.

106. Abdul-Careem MF, Lee AJ, Pek EA, Gill N, Gillgrass AE, Chew MV, Reid S, Ashkar AA. Genital HSV-2 infection induces short-term NK cell memory. PloS One. 2012;7:e32821.

107. Lopez-Verges S, Milush JM, Schwartz BS, Pando MJ, Jarjoura J, York VA, Houchins JP, Miller S, Kang SM, Norris PJ, Nixon DF, Lanier LL. Expansion of a unique CD57(+)NKG2Chi natural killer cell subset during acute human cytomegalovirus infection. Proc Natl Acad Sci U S A. 2011;108:14725-32.

108. Bjorkstrom NK, Lindgren T, Stoltz M, Fauriat C, Braun M,Evander M, Michaelsson J, Malmberg KJ, Klingstrom J, Ahlm C, Ljunggren HG. Rapid expansion and longterm persistence of elevated NK cell numbers in humans infected with hantavirus. J Exp Med. 2011;208:13-21.

109. Paust S, Gill HS, Wang BZ, Flynn MP, Moseman EA, Senman B, Szczepanik M, Telenti A, Askenase PW, Compans RW, von Andrian UH. Critical role for the chemokine receptor CXCR6 in NK cell-mediated antigen-specific memory of haptens and viruses. Nat Immunol. 2010;11:1127-35.

110. Schlub TE, Sun JC, Walton SM, Robbins SH, Pinto AK, Munks MW, Hill AB, Brossay L, Oxenius A, Davenport MP. Comparing the kinetics of NK cells, CD4, and CD8 $\mathrm{T}$ cells in murine cytomegalovirus infection. J Immunol. 2011;187:1385-92.

111. Romee R, Schneider SE, Leong JW, Chase JM, Keppel CR, Sullivan RP, Cooper MA, Fehniger TA. Cytokine activation induces human memory-like NK cells. Blood. 2012;120:4751-60.

112. Ni J, Miller M, Stojanovic A, Garbi N, Cerwenka A. Sustained effector function of IL-12/15/18-preactivated NK cells against established tumors. J Exp Med. 2012;209:2351-65.

113. Cooper MA, Elliott JM, Keyel PA, Yang L, Carrero JA, Yokoyama WM. Cytokine-induced memory-like natural killer cells. Proc Natl Acad Sci U S A. 2009;106:1915-9.

114. Sun JC, Madera S, Bezman NA, Beilke JN, Kaplan MH, Lanier LL. Proinflammatory cytokine signaling required for the generation of natural killer cell memory. J Exp Med. 2012;209:947-54.

115. Keppel MP, Yang L, Cooper MA. Murine NK cell intrinsic cytokine-induced memory-like responses are maintained following homeostatic proliferation. J Immunol. 2013;190:4754-62.

116. Cichocki F, Miller JS, Anderson SK, Bryceson YT. Epigenetic regulation of NK cell differentiation and effector functions. Front Immunol. 2013;4:55.

117. Francois S, Peng J, Schwarz T, Duppach J, Gibbert K, Dittmer U, Kraft AR. NK cells improve control of friend virus infection in mice persistently infected with murine cytomegalovirus. Retrovirology. 2013;10:58.

118. White DW, Keppel CR, Schneider SE, Reese TA, Coder J, Payton JE, Ley TJ, Virgin HW, Fehniger TA. Latent herpesvirus infection arms NK cells. Blood. 2010;115:4377-83.

119. Cook KD, Whitmire JK. The depletion of NK cells prevents $\mathrm{T}$ cell exhaustion to efficiently control disseminating virus infection.J Immunol. 2013;190:641-9.

120. Wang Y, Swiecki M, Cella M, Alber G, Schreiber RD, Gilfillan S, Colonna M. Timing and magnitude of type I interferon responses by distinct sensors impact CD8 $\mathrm{T}$ cell exhaustion and chronic viral infection. Cell Host Microbe. 2012;11:631-42.

121. Sevilla N, McGavern DB, Teng C, Kunz S, Oldstone MB. Viral targeting of hematopoietic progenitors and inhibition of DC maturation as a dual strategy for immune subversion. J Clin Invest. 2004;113:737-45.

122. Sevilla N, Kunz S, Holz A, Lewicki H, Homann D, Yamada H, Campbell KP, de La Torre JC, Oldstone MB. Immunosuppression and resultant viral persistence by specific viral targeting of dendritic cells. J Exp Med. 2000;192:1249-60.

123. Borrow P, Evans CF, Oldstone MB. Virus-induced immunosuppression: immune system-mediated destruction of virus-infected dendritic cells results in generalized immune suppression. J Virol. 1995;69:1059-70.

124. Mueller SN, Matloubian M, Clemens DM, Sharpe AH, Freeman GJ, Gangappa S, Larsen CP, Ahmed R. Viral targeting of fibroblastic reticular cells contributes to immunosuppression and persistence during chronic infection. Proc Natl Acad Sci U S A. 2007;104:15430-5.

125. Wilson EB, Yamada DH, Elsaesser H, Herskovitz J, Deng J, Cheng G, Aronow BJ, Karp CL, Brooks DG. Blockade of chronic type I interferon signaling to control persistent LCMV infection. Science. 2013;340:202-7.

126. Teijaro JR, Ng C, Lee AM, Sullivan BM, Sheehan KC, Welch M, Schreiber RD, de la Torre JC, Oldstone MB. Persistent LCMV infection is controlled by blockade of type I interferon signaling. Science. 2013;340:207-11.

127. Gasteiger G, Hemmers S, Bos PD, Sun JC, Rudensky AY. IL-2-dependent adaptive control of NK cell homeostasis. J Exp Med. 2013;210:1179-87.

128. Vieillard V, Strominger JL, Debre P. NK cytotoxicity against CD4+ T cells during HIV-1 infection: a gp41 peptide induces the expression of an NKp44 ligand. Proc Natl Acad Sci U S A. 2005;102:10981-6.

129. Pembroke T, Christian A, Jones E, Hills RK, Wang EC, Gallimore AM, Godkin A. The paradox of NKp46+ natural killer cells: drivers of severe hepatitis $\mathrm{C}$ virusinduced pathology but in-vivo resistance to interferon alpha treatment. Gut. 2013;10.1136/gutjnl-2013-304472.

130. De Maria A, Fogli M, Costa P, Murdaca G, Puppo F, Mavilio D, Moretta A, Moretta L. The impaired NK 
cell cytolytic function in viremic $\mathrm{HIV}-1$ infection is associated with a reduced surface expression of natural cytotoxicity receptors (NKp46, NKp30 and NKp44). Eur J Immunol. 2003;33:2410-8.

131. Fogli M, Costa P, Murdaca G, Setti M, Mingari MC, Moretta L, Moretta A, De Maria A. Significant NK cell activation associated with decreased cytolytic function in peripheral blood of HIV-1-infected patients. Eur J Immunol. 2004;34:2313-21.

132. Mavilio D, Lombardo G, Benjamin J, Kim D, Follman D, Marcenaro E, O'Shea MA, Kinter A, Kovacs C, Moretta A, Fauci AS. Characterization of CD56-/ CD16+ natural killer (NK) cells: a highly dysfunctional NK subset expanded in HIV-infected viremic individuals. Proc Natl Acad Sci U S A. 2005;102:2886-91.

133. Mavilio D, Lombardo G, Kinter A, Fogli M, La Sala A, Ortolano S, Farschi A, Follmann D, Gregg R, Kovacs C, Marcenaro E, Pende D, Moretta A, Fauci AS. Characterization of the defective interaction between a subset of natural killer cells and dendritic cells in HIV-1 infection. J Exp Med. 2006;203:2339-50.

134. Alter G, Kavanagh D, Rihn S, Luteijn R, Brooks D, Oldstone M, van Lunzen J, Altfeld M. IL-10 induces aberrant deletion of dendritic cells by natural killer cells in the context of HIV infection. J Clin Invest. 2010;120:1905-13.

135. Alter G, Martin MP, Teigen N, Carr WH, Suscovich TJ, Schneidewind A, Streeck H, Waring M, Meier A, Brander C, Lifson JD, Allen TM, Carrington M, Altfeld M. Differential natural killer cell-mediated inhibition of HIV-1 replication based on distinct KIR/HLA subtypes. J Exp Med. 2007;204:3027-36.

136. Bonorino P, Ramzan M, Camous X, Dufeu-Duchesne T, Thelu MA, Sturm N, Dariz A, Guillermet C, Pernollet M, Zarski JP, Marche PN, Leroy V, Jouvin-Marche E. Fine characterization of intrahepatic NK cells expressing natural killer receptors in chronic hepatitis B and C. J Hepatol. 2009;51:458-67.

137. Golden-Mason L, Madrigal-Estebas L, McGrath E, Conroy MJ, Ryan EJ, Hegarty JE, O'Farrelly C, Doherty DG. Altered natural killer cell subset distributions in resolved and persistent hepatitis $\mathrm{C}$ virus infection following single source exposure. Gut. 2008;57:1121-8.

138. Morishima C, Paschal DM, Wang CC, Yoshihara CS, Wood BL, Yeo AE, Emerson SS, Shuhart MC, Gretch DR. Decreased NK cell frequency in chronic hepatitis $\mathrm{C}$ does not affect ex vivo cytolytic killing. Hepatology. 2006;43:573-80.

139. Oliviero B, Varchetta S, Paudice E, Michelone G, Zaramella M, Mavilio D, De Filippi F, Bruno S, Mondelli MU. Natural killer cell functional dichotomy in chronic hepatitis B and chronic hepatitis $\mathrm{C}$ virus infections. Gastroenterology. 2009;137:1151-60, 60 e1-7.
140. Bonavita MS, Franco A, Paroli M, Santilio I, Benvenuto R, De Petrillo G, Levrero M, Perrone A, Balsano C, Barnaba V. Normalization of depressed natural killer activity after interferon-alpha therapy is associated with a low frequency of relapse in patients with chronic hepatitis C. Int J Tissue React. 1993;15:11-6.

141. Dessouki O, Kamiya Y, Nagahama H, Tanaka M, Suzu $\mathrm{S}$, Sasaki Y, Okada S. Chronic hepatitis $\mathrm{C}$ viral infection reduces NK cell frequency and suppresses cytokine secretion: Reversion by anti-viral treatment. Biochem Biophys Res Commun. 2010;393:331-7.

142. Alter G, Heckerman D, Schneidewind A, Fadda L, Kadie CM, Carlson JM, Oniangue-Ndza C, Martin M, Li B, Khakoo SI, Carrington M, Allen TM, Altfeld M. HIV-1 adaptation to NK-cell-mediated immune pressure. Nature. 2011;476:96-100.

143. Waggoner SN, Daniels KA, Welsh RM. Therapeutic depletion of natural killer cells controls persistent infection. J Virol. 2013;10.1128/JVI.03002-13.

144. De Maria A, Bozzano F, Cantoni C, Moretta L. Revisiting human natural killer cell subset function revealed cytolytic CD56(dim)CD16+ NK cells as rapid producers of abundant IFN-gamma on activation. Proc Natl Acad Sci U S A. 2011;108:728-32.

145. Stetson DB, Mohrs M, Reinhardt RL, Baron JL, Wang ZE, Gapin L, Kronenberg M, Locksley RM. Constitutive cytokine mRNAs mark natural killer (NK) and NK $\mathrm{T}$ cells poised for rapid effector function. J Exp Med. 2003;198:1069-76.

146. Whitmire JK, Eam B, Benning N, Whitton JL. Direct interferon-gamma signaling dram-atically enhances CD4+ and CD8+ T cell memory. J Immunol. 2007;179:1190-7.

147. Whitmire JK, Tan JT, Whitton JL. Interferon-gamma acts directly on CD8+ T cells to increase their abundance during virus infection. J Exp Med. 2005;201:1053-9.

148. Whitmire JK, Benning N, Whitton JL. Cutting edge: early IFN-gamma signaling directly enhances primary antiviral CD4+ T cell responses. J Immunol. 2005;175:5624-8.

149. Scharton TM, Scott P. Natural killer cells are a source of interferon gamma that drives differentiation of CD4+ T cell subsets and induces early resistance to Leishmania major in mice. J Exp Med. 1993;178:567-77.

150. Martin-Fontecha A, Thomsen LL, Brett S, Gerard C, Lipp M, Lanzavecchia A, Sallusto F. Induced recruitment of NK cells to lymph nodes provides IFN-gamma for $\mathrm{T}(\mathrm{H}) 1$ priming. Nature Immunol. 2004;5:1260-5.

151. Kos FJ, Engleman EG. Role of natural killer cells in the generation of influenza virus-specific cytotoxic $\mathrm{T}$ cells. Cell Immunol. 1996;173:1-6.

152. Ge MQ, Ho AW, Tang Y, Wong KH, Chua BY, Gasser $\mathrm{S}$, Kemeny DM. NK cells regulate CD8+ T cell priming and dendritic cell migration during influenza $\mathrm{A}$ infection 
by IFN-gamma and perforin-dependent mechanisms. J Immunol. 2012;189:2099-109.

153. Gray JD, Hirokawa M, Ohtsuka K, Horwitz DA. Generation of an inhibitory circuit involving CD8+ T cells, IL-2, and NK cell-derived TGF-beta: contrasting effects of anti-CD2 and anti-CD3. J Immunol. 1998;160:2248-54.

154. Mehrotra PT, Donnelly RP, Wong S, Kanegane H, Geremew A, Mostowski HS, Furuke K, Siegel JP, Bloom ET. Production of IL-10 by human natural killer cells stimulated with IL-2 and/or IL-12. J Immunol. 1998;160:2637-44.

155. Moore KW, de Waal Malefyt R, Coffman RL, O'Garra A. Interleukin-10 and the interleukin-10 receptor. Annu Rev Immunol. 2001;19:683-765.

156. Gorelik L, Flavell RA. Abrogation of TGFbeta signaling in $\mathrm{T}$ cells leads to spontaneous $\mathrm{T}$ cell differentiation and autoimmune disease. Immunity. 2000;12:171-81.

157. Deniz G, Erten G, Kucuksezer UC, Kocacik D, Karagiannidis C, Aktas E, Akdis CA, Akdis M. Regulatory NK cells suppress antigen-specific $\mathrm{T}$ cell responses. J Immunol. 2008;180:850-7.

158. Perona-Wright G, Mohrs K, Szaba FM, Kummer LW, Madan R, Karp CL, Johnson LL, Smiley ST, Mohrs M. Systemic but not local infections elicit immunosuppressive IL-10 production by natural killer cells. Cell Host Microbe. 2009;6:503-12.

159. Lee SH, Kim KS, Fodil-Cornu N, Vidal SM, Biron CA. Activating receptors promote NK cell expansion for maintenance, IL-10 production, and CD8 $\mathrm{T}$ cell regulation during viral infection. J Exp Med. 2009;206:2235-51.

160. De Maria A, Fogli M, Mazza S, Basso M, Picciotto A, Costa P, Congia S, Mingari MC, Moretta L. Increased natural cytotoxicity receptor expression and relevant IL-10 production in NK cells from chronically infected viremic $\mathrm{HCV}$ patients. Eur J Immunol. 2007;37:445-55.

161. Fauci AS, Mavilio D, Kottilil S. NK cells in HIV infection: paradigm for protection or targets for ambush. Nat Rev Immunol. 2005;5:835-43.

162. Mondelli MU, Varchetta S, Oliviero B. Natural killer cells in viral hepatitis: facts and controversies. Eur J Clin Invest. 2010;40:851-63.

163. Long EO, Kim HS, Liu D, Peterson ME, Rajagopalan S. Controlling natural killer cell responses: integration of signals for activation and inhibition. Annu Rev Immunol. 2013;31:227-58.

164. Vidal SM, Khakoo SI, Biron CA. Natural killer cell responses during viral infections: flexibility and conditioning of innate immunity by experience. Curr Opin Virol. 2011;1:497-512.

165. Zwirner NW,Domaica CI. Cytokine regulation of natural killer cell effector functions. BioFactors. 2010;36:274-88.
166. Barthlott T, Moncrieffe H, Veldhoen M, Atkins CJ, Christensen J, O'Garra A, Stockinger B. CD25+ CD4+ T cells compete with naive CD4+ T cells for IL-2 and exploit it for the induction of IL-10 production. Int Immunol. 2005;17:279-88.

167. Pandiyan P, Zheng L, Ishihara S, Reed J, Lenardo MJ. $\mathrm{CD} 4+\mathrm{CD} 25+\mathrm{Foxp} 3+$ regulatory $\mathrm{T}$ cells induce cytokine deprivation-mediated apoptosis of effector CD4+ T cells. Nat Immunol. 2007;8:1353-62.

168. Lee SH, Fragoso MF, Biron CA. Cutting edge: a novel mechanism bridging innate and adaptive immunity: IL-12 induction of CD25 to form high-affinity IL-2 receptors on NK cells. J Immunol. 2012;189:2712-6.

169. Su HC, Orange JS, Fast LD, Chan AT, Simpson SJ, Terhorst C, Biron CA. IL-2-dependent NK cell responses discovered in virus-infected beta 2-microglobulindeficient mice. J Immunol. 1994;153:5674-81.

170. Zecher D, Li Q, Oberbarnscheidt MH, Demetris AJ, Shlomchik WD, Rothstein DM, Lakkis FG. NK cells delay allograft rejection in lymphopenic hosts by downregulating the homeostatic proliferation of CD8+ T cells. J Immunol. 2010;184:6649-57.

171. Hansson M, Karre K, Kiessling R, Roder J, Andersson B, Hayry P. Natural NK-cell targets in the mouse thymus: characteristics of the sensitive cell population.J Immunol. 1979;123:765-71.

172. Hansson M, Kiessling R, Andersson B, Karre K, Roder J. NK cell-sensitive T-cell subpopulation in thymus: inverse correlation to host NK activity. Nature. 1979;278:174-6.

173. Schott E, Bonasio R, Ploegh HL. Elimination in vivo of developing T cells by natural killer cells. J Exp Med. 2003;198:1213-24.

174. Rabinovich BA, Li J, Shannon J, Hurren R, Chalupny J, Cosman D, Miller RG. Activated, but not resting, T cells can be recognized and killed by syngeneic NK cells. J Immunol. 2003;170:3572-6.

175. Cerboni C, Zingoni A, Cippitelli M, Piccoli M, Frati L, Santoni A. Antigen-activated human T lymphocytes express cell-surface NKG2D ligands via an ATM/ ATR-dependent mechanism and become susceptible to autologous NK- cell lysis. Blood. 2007;110:606-15.

176. Soderquest K, Walzer T, Zafirova B, Klavinskis LS, Polic B, Vivier E, Lord GM, Martin-Fontecha A. Cutting edge: CD8 $+\mathrm{T}$ cell priming in the absence of NK cells leads to enhanced memory responses. J Immunol. 2011;186:3304-8.

177. Nielsen N, Odum N, Urso B, Lanier LL, Spee P. Cytotoxicity of CD56(bright) NK cells towards autologous activated CD4+ T cells is mediated through NKG2D, LFA-1 and TRAIL and dampened via CD94/ NKG2A. PloS One. 2012;7:e31959.

178. Jamieson AM, Diefenbach A, McMahon CW, Xiong N, Carlyle JR, Raulet DH. The role of the NKG2D 
immunoreceptor in immune cell activation and natural killing. Immunity. 2002;17:19-29.

179. Sutherland CL, Chalupny NJ, Schooley K, VandenBos T, Kubin M, Cosman D. UL16-binding proteins, novel MHC class I-related proteins, bind to NKG2D and activate multiple signaling pathways in primary NK cells. J Immunol. 2002;168:671-9.

180. Yabe T, McSherry C, Bach FH, Fisch P, Schall RP, Sondel PM, Houchins JP. A multigene family on human chromosome 12 encodes natural killer-cell lectins. Immunogenetics. 1993;37:455-60.

181. Raulet DH, Gasser S, Gowen BG, Deng W, Jung H. Regulation of ligands for the NKG2D activating receptor. Annu Rev Immunol. 2013;31:413-41.

182. Peppa D, Gill US, Reynolds G, Easom NJ, Pallett LJ, Schurich A, Micco L, Nebbia G, Singh HD, Adams DH, Kennedy PT, Maini MK. Up-regulation of a death receptor renders antiviral $\mathrm{T}$ cells susceptible to NK cellmediated deletion. J Exp Med. 2013;210:99-114.

183. Roy S, Barnes PF, Garg A, Wu S, Cosman D, Vankayalapati R. NK cells lyse $T$ regulatory cells that expand in response to an intracellular pathogen. J Immunol. 2008;180:1729-36.

184. Takao S, Ishikawa T, Yamashita K, Uchiyama T. The rapid induction of HLA-E is essential for the survival of antigen-activated naive CD4 $\mathrm{T}$ cells from attack by NK cells. J Immunol. 2010;185:6031-40.

185. Lu L, Ikizawa K, Hu D, Werneck MB, Wucherpfennig KW, Cantor H. Regulation of activated CD4+ T cells by NK cells via the Qa-1-NKG2A inhibitory pathway. Immunity. 2007;26:593-604.

186. Fort MM, Leach MW, Rennick DM. A role for NK cells as regulators of CD4+ T cells in a transfer model of colitis. J Immunol. 1998;161:3256-61.

187. Leavenworth JW, Wang X, Wenander CS, Spee P, Cantor H. Mobilization of natural killer cells inhibits development of collagen-induced arthritis. Proc Natl Acad Sci U S A. 2011;108:14584-9.

188. Waggoner SN, Cornberg M, Selin LK, Welsh RM. Natural killer cells act as rheostats modulating antiviral T cells. Nature. 2012;481:394-8.

189. Lang PA, Lang KS, Xu HC, Grusdat M, Parish IA, Recher M, Elford AR, Dhanji S, Shaabani N, Tran CW, Dissanayake D, Rahbar R, Ghazarian M, Brustle A, Fine J, Chen P, Weaver CT, Klose C, Diefenbach A, Haussinger D, Carlyle JR, Kaech SM, Mak TW, Ohashi PS. Natural killer cell activation enhances immune pathology and promotes chronic infection by limiting CD8+ T-cell immunity. Proc Natl Acad Sci U S A. 2012;109:1210-5.

190. Su HC, Nguyen KB, Salazar-Mather TP, Ruzek MC, Dalod MY, Biron CA. NK cell functions restrain $\mathrm{T}$ cell responses during viral infections. Eur J Immunol. 2001;31:3048-55.
191. Yi JS, Du M, Zajac AJ. A vital role for interleukin-21 in the control of a chronic viral infection. Science. 2009;324:1572-6.

192. Zajac AJ, Blattman JN, Murali-Krishna K, Sourdive DJ, Suresh M, Altman JD, Ahmed R. Viral immune evasion due to persistence of activated T cells without effector function. J Exp Med. 1998;188:2205-13.

193. Elsaesser H, Sauer K, Brooks DG. IL-21 is required to control chronic viral infection. Science. 2009;324:1569-72.

194. Frohlich A, Kisielow J, Schmitz I, Freigang S, Shamshiev AT, Weber J, Marsland BJ, Oxenius A, Kopf M. IL-21R on T cells is critical for sustained functionality and control of chronic viral infection. Science. 2009;324:1576-80.

195. Waggoner SN, Taniguchi RT, Mathew PA, Kumar V, Welsh RM. Absence of mouse 2B4 promotes NK cellmediated killing of activated CD8+ T cells, leading to prolonged viral persistence and altered pathogenesis. J Clin Invest. 2010;120:1925-38.

196. Chlewicki LK, Velikovsky CA, Balakrishnan V, Mariuzza RA, Kumar V. Molecular basis of the dual functions of 2B4 (CD244). J Immunol. 2008;180:8159-67.

197. Claus M, Meinke S, Bhat R, Watzl C. Regulation of NK cell activity by $2 \mathrm{~B} 4$, NTB-A and CRACC. Front Biosci. 2008;13:956-65.

198. Vaidya SV, Mathew PA. Of mice and men: different functions of the murine and human 2B4 (CD244) receptor on NK cells. Immunol Lett. 2006;105:180-4.

199. Lee KM, McNerney ME, Stepp SE, Mathew PA, Schatzle JD, Bennett M, Kumar V. 2B4 acts as a nonmajor histocompatibility complex binding inhibitory receptor on mouse natural killer cells. J Exp Med. 2004;199:1245-54.

200. Vaidya SV, Stepp SE, McNerney ME, Lee JK, Bennett M, Lee KM, Stewart CL, Kumar V, Mathew PA. Targeted disruption of the $2 \mathrm{~B} 4$ gene in mice reveals an in vivo role of 2B4 (CD244) in the rejection of B16 melanoma cells. J Immunol. 2005;174:800-7.

201. Sprick MR, Weigand MA, Rieser E, Rauch CT, Juo P, Blenis J, Krammer PH, Walczak H. FADD/MORT1 and caspase- 8 are recruited to TRAIL receptors 1 and 2 and are essential for apoptosis mediated by TRAIL receptor 2. Immunity. 2000;12:599-609.

202. Peppa D, Micco L, Javaid A, Kennedy PT, Schurich A, Dunn C, Pallant C, Ellis G, Khanna P, Dusheiko G, Gilson RJ, Maini MK. Blockade of immunosuppressive cytokines restores NK cell antiviral function in chronic hepatitis B virus infection. PLoS Pathogens. 2010;6:e1001227.

203. Dunn C, Brunetto M, Reynolds G, Christophides T, Kennedy PT, Lampertico P, Das A, Lopes AR, Borrow P, Williams K, Humphreys E, Afford S, Adams DH, Bertoletti A, Maini MK. Cytokines induced during chronic hepatitis B virus infection promote a pathway 
for NK cell-mediated liver damage. J Exp Med. 2007;204:667-80.

204. Steinman RM. Decisions about dendritic cells: past, present, and future. Annu Rev Immunol. 2012;30:1-22.

205. Bajenoff M, Breart B, Huang AY, Qi H, Cazareth J, Braud VM, Germain RN, Glaichenhaus N. Natural killer cell behavior in lymph nodes revealed by static and real-time imaging. J Exp Med. 2006;203:619-31.

206. Piccioli D, Sbrana S, Melandri E, Valiante NM. Contactdependent stimulation and inhibition of dendritic cells by natural killer cells. J Exp Med. 2002;195:335-41.

207. Gerosa F, Baldani-Guerra B, Nisii C, Marchesini V, Carra G, Trinchieri G. Reciprocal activating interaction between natural killer cells and dendritic cells. J Exp Med. 2002;195:327-33.

208. Vitale M, Della Chiesa M, Carlomagno S, Pende D, Arico M, Moretta L, Moretta A. NK-dependent DC maturation is mediated by TNFalpha and IFNgamma released upon engagement of the NKp30 triggering receptor. Blood. 2005;106:566-71.

209. Simhadri VR, Reiners KS, Hansen HP, Topolar D, Simhadri VL, Nohroudi K, Kufer TA, Engert A, Pogge von Strandmann E. Dendritic cells release HLA-Bassociated transcript-3 positive exosomes to regulate natural killer function. PloS One. 2008;3:e3377.

210. Semino C, Angelini G, Poggi A, Rubartelli A. NK/ iDC interaction results in IL-18 secretion by DCs at the synaptic cleft followed by NK cell activation and release of the DC maturation factor HMGB1. Blood. 2005;106:609-16.

211. Jinushi M, Takehara T, Tatsumi T, Kanto T, Miyagi T, Suzuki T, Kanazawa Y, Hiramatsu N, Hayashi N. Negative regulation of NK cell activities by inhibitory receptor CD94/NKG2A leads to altered NK cellinduced modulation of dendritic cell functions in chronic hepatitis $\mathrm{C}$ virus infection. J Immunol. 2004;173:6072-81.

212. Jiao L, Gao X, Joyee AG, Zhao L, Qiu H, Yang M, Fan Y, Wang S, Yang X. NK cells promote type $1 \mathrm{~T}$ cell immunity through modulating the function of dendritic cells during intracellular bacterial infection. J Immunol. 2011;187:401-11.

213. Mandaric S, Walton SM, Rulicke T, Richter K, GirardMadoux MJ, Clausen BE, Zurunic A, Kamanaka M, Flavell RA, Jonjic S, Oxenius A. IL-10 suppression of NK/DC crosstalk leads to poor priming of MCMVspecific CD4 T cells and prolonged MCMV persistence. PLoS Pathogens. 2012;8:e1002846.

214. Andrews DM, Scalzo AA, Yokoyama WM, Smyth MJ, Degli-Esposti MA. Functional interactions between dendritic cells and NK cells during viral infection. Nat Immunol. 2003;4:175-81.

215. Scalzo AA, Brown MG, Chu DT, Heusel JW, Yokoyama WM, Forbes CA. Development of intra-natural killer complex (NKC) recombinant and congenic mouse strains for mapping and functional analysis of NK cell regulatory loci. Immunogenetics. 1999;49:238-41.

216. Robbins SH, Bessou G, Cornillon A, Zucchini N, Rupp B, Ruzsics Z, Sacher T, Tomasello E, Vivier E, Koszinowski UH, Dalod M. Natural killer cells promote early CD8 T cell responses against cytomegalovirus. PLoS Pathogens. 2007;3:e123.

217. Hung K, Hayashi R, Lafond-Walker A, Lowenstein C, Pardoll D, Levitsky H. The central role of CD4(+) $\mathrm{T}$ cells in the antitumor immune response. J Exp Med. 1998;188:2357-68.

218. Husmann LA, Bevan MJ. Cooperation between helper $\mathrm{T}$ cells and cytotoxic $\mathrm{T}$ lymphocyte precursors. Ann N Y Acad Sci. 1988;532:158-69.

219. Keene JA, Forman J. Helper activity is required for the in vivo generation of cytotoxic $\mathrm{T}$ lymphocytes. J Exp Med. 1982;155:768-82.

220. Bennett SR, Carbone FR, Karamalis F, Flavell RA, Miller JF, Heath WR. Help for cytotoxic-T-cell responses is mediated by CD40 signalling. Nature. 1998;393:478-80.

221. Schoenberger SP, Toes RE, van der Voort EI, Offringa $\mathrm{R}$, Melief CJ. T-cell help for cytotoxic $\mathrm{T}$ lymphocytes is mediated by CD40-CD40L interactions. Nature. 1998;393:480-3.

222. Ridge JP,Di Rosa F,Matzinger P. A conditioned dendritic cell can be a temporal bridge between a CD4+ T-helper and a T-killer cell. Nature. 1998;393:474-8.

223. Adam C, King S, Allgeier T, Braumuller H, Luking C, Mysliwietz J, Kriegeskorte A, Busch DH, Rocken M, Mocikat R. DC-NK cell cross talk as a novel CD4+ T-cell-independent pathway for antitumor CTL induction. Blood. 2005;106:338-44.

224. Combe CL, Curiel TJ, Moretto MM, Khan IA. NK cells help to induce CD8(+)-T-cell immunity against Toxoplasma gondii in the absence of CD4(+) T cells. Infect Immun. 2005;73:4913-21.

225. Nandakumar S, Woolard SN, Yuan D, Rouse BT, Kumaraguru U. Natural killer cells as novel helpers in anti-herpes simplex virus immune response. J Virol. 2008;82:10820-31.

226. Barber MA, Zhang T, Gagne BA, Sentman CL. NK cells negatively regulate antigen presentation and tumor-specific CTLs in a syngeneic lymphoma model. J Immunol. 2007;178:6140-7.

227. Ferlazzo G,Morandi B, D’Agostino A, Meazza R, Melioli G, Moretta A, Moretta L. The interaction between NK cells and dendritic cells in bacterial infections results in rapid induction of NK cell activation and in the lysis of uninfected dendritic cells. Eur J Immunol. 2003;33:306-13.

228. Ferlazzo G, Tsang ML, Moretta L, Melioli G, Steinman RM, Munz C. Human dendritic cells activate resting natural killer (NK) cells and are recognized via the 
NKp30 receptor by activated NK cells. J Exp Med. 2002;195:343-51.

229. Wilson JL, Heffler LC, Charo J, Scheynius A, Bejarano MT, Ljunggren HG. Targeting of human dendritic cells by autologous NK cells. J Immunol. 1999;163:6365-70.

230. Pende D, Castriconi R, Romagnani P, Spaggiari GM, Marcenaro S, Dondero A, Lazzeri E, Lasagni L, Martini S, Rivera P, Capobianco A, Moretta L, Moretta A, Bottino C. Expression of the DNAM-1 ligands, Nectin-2 (CD112) and poliovirus receptor (CD155), on dendritic cells: relevance for natural killer-dendritic cell interaction. Blood. 2006;107:2030-6.

231. Hayakawa Y, Screpanti V, Yagita H, Grandien A, Ljunggren HG, Smyth MJ, Chambers BJ. NK cell TRAIL eliminates immature dendritic cells in vivo and limits dendritic cell vaccination efficacy. J Immunol. 2004;172:123-9.

232. Andrews DM, Estcourt MJ, Andoniou CE, Wikstrom ME, Khong A, Voigt V, Fleming P, Tabarias H, Hill GR, van der Most RG, Scalzo AA, Smyth MJ, DegliEsposti MA. Innate immunity defines the capacity of antiviral T cells to limit persistent infection. J Exp Med. 2010;207:1333-43.

233. Morandi B, Mortara L, Chiossone L,Accolla RS, Mingari MC, Moretta L, Moretta A, Ferlazzo G. Dendritic cell editing by activated natural killer cells results in a more protective cancer-specific immune response. PloS One. 2012;7:e39170.

234. Welsh RM, O’Donnell CL, Shultz LD. Antiviral activity of NK 1.1+ natural killer cells in C57BL/6 scid mice infected with murine cytomegalovirus. Nat Immun. 1994;13:239-45.

235. Murphy KM, Reiner SL. The lineage decisions of helper T cells. Nat Rev Immunol. 2002;2:933-44.

236. Smith-Garvin JE, Koretzky GA, Jordan MS. T cell activation. Annu Rev Immunol. 2009;27:591-619.

237. Ferber I, Schonrich G, Schenkel J, Mellor AL, Hammerling GJ, Arnold B. Levels of peripheral T cell tolerance induced by different doses of tolerogen. Science. 1994;263:674-6.

238. Critchfield JM, Racke MK, Zuniga-Pflucker JC, Cannella B, Raine CS, Goverman J, Lenardo MJ. T cell deletion in high antigen dose therapy of autoimmune encephalomyelitis. Science. 1994;263:1139-43.

239. Zajac AJ, Blattman JN, Murali-Krishna K, Sourdive DJ, Suresh M, Altman JD, Ahmed R. Viral immune evasion due to persistence of activated $\mathrm{T}$ cells without effector function. J Exp Med. 1998;188:2205-13.

240. Mitrovic M, Arapovic J, Jordan S, Fodil-Cornu N, Ebert S, Vidal SM, Krmpotic A, Reddehase MJ, Jonjic S. The NK cell response to mouse cytomegalovirus infection affects the level and kinetics of the early CD8(+) T-cell response. J Virol. 2012;86:2165-75.
241. Bukowski JF, Woda BA, Welsh RM. Pathogenesis of murine cytomegalovirus infection in natural killer celldepleted mice. J Virol. 1984;52:119-28.

242. Fang M, Roscoe F, Sigal LJ. Age-dependent susceptibility to a viral disease due to decreased natural killer cell numbers and trafficking. J Exp Med. 2010;207:2369-81.

243. Krebs P, Barnes MJ, Lampe K, Whitley K, Bahjat KS, Beutler B, Janssen E, Hoebe K. NK-cell-mediated killing of target cells triggers robust antigen-specific T-cell-mediated and humoral responses. Blood. 2009;113:6593-602.

244. Kelly JM, Darcy PK, Markby JL, Godfrey DI, Takeda K, Yagita H, Smyth MJ. Induction of tumor-specific $\mathrm{T}$ cell memory by NK cell-mediated tumor rejection. Nat Immunol. 2002;3:83-90.

245. Ghiringhelli F, Menard C, Terme M, Flament C, Taieb J, Chaput N, Puig PE, Novault S, Escudier B, Vivier E, Lecesne A, Robert C, BlayJY, Bernard J, Caillat-Zucman S, Freitas A, Tursz T, Wagner-Ballon O, Capron C, Vainchencker W, Martin F, Zitvogel L. CD4+CD25+ regulatory $\mathrm{T}$ cells inhibit natural killer cell functions in a transforming growth factor-beta-dependent manner. J Exp Med. 2005;202:1075-85.

246. Sungur CM, Tang-Feldman YJ, Ames E, Alvarez M, Chen M, Longo DL, Pomeroy C, Murphy WJ. Murine natural killer cell licensing and regulation by $\mathrm{T}$ regulatory cells in viral responses. Proc Natl Acad Sci U S A. 2013;110:7401-6.

247. Kerdiles Y, Ugolini S, Vivier E. T cell regulation of natural killer cells. J Exp Med. 2013;210:1065-8.

248. Gasteiger G, Hemmers S, Firth MA, Le Floc'h A, Huse M, Sun JC, Rudensky AY.IL-2-dependent tuning of NK cell sensitivity for target cells is controlled by regulatory T cells. J Exp Med. 2013;210:1167-78.

249. Sitrin J, Ring A, Garcia KC, Benoist C, Mathis D. Regulatory $\mathrm{T}$ cells control NK cells in an insulitic lesion by depriving them of IL-2.J Exp Med. 2013;210:1153-65.

250. Kelly MN, Zheng M, Ruan S, Kolls J, D’Souza A, Shellito JE. Memory CD4+ T cells are required for optimal NK cell effector functions against the opportunistic fungal pathogen Pneumocystis murina. J Immunol. 2013;190:285-95.

251. Horowitz A, Newman KC, Evans JH, Korbel DS, Davis DM, Riley EM. Cross-talk between T cells and NK cells generates rapid effector responses to Plasmodium falciparum-infected erythrocytes. J Immunol. 2010;184:6043-52.

252. Bihl F, Pecheur J, Breart B, Poupon G, Cazareth J, Julia V, Glaichenhaus N, Braud VM. Primed antigen-specific $\mathrm{CD} 4+\mathrm{T}$ cells are required for $\mathrm{NK}$ cell activation in vivo upon Leishmania major infection. J Immunol. 2010;185:2174-81.

253. Vargas-Inchaustegui DA, Xiao P, Tuero I, Patterson LJ, Robert-Guroff M. NK and CD4+ T cell cooperative 
immune responses correlate with control of disease in a macaque simian immunodeficiency virus infection model. J Immunol. 2012;189:1878-85.

254. Horowitz A, Behrens RH, Okell L, Fooks AR, Riley EM. NK cells as effectors of acquired immune responses: effector $\mathrm{CD} 4+\mathrm{T}$ cell-dependent activation of NK cells following vaccination. J Immunol. 2010;185:2808-18.

255. Nabel G, Allard WJ, Cantor H. A cloned cell line mediating natural killer cell function inhibits immunoglobulin secretion.J Exp Med. 1982;156:658-63.

256. Abruzzo LV, Rowley DA. Homeostasis of the antibody response: immunoregulation by NK cells. Science. 1983;222:581-5.

257. Storkus WJ, Dawson JR. B cell sensitivity to natural killing: correlation with target cell stage of differentiation and state of activation. J Immunol. 1986;136:1542-7.

258. Shah PD, Gilbertson SM, Rowley DA. Dendritic cells that have interacted with antigen are targets for natural killer cells. J Exp Med. 1985;162:625-36.

259. Koh CY, Yuan D. The functional relevance of NKcell-mediated upregulation of antigen-specific IgG2a responses. Cell Immunol. 2000;204:135-42.

260. Gao N, Jennings P, Yuan D. Requirements for the natural killer cell-mediated induction of $\operatorname{IgG1}$ and IgG2a expression in B lymphocytes. Int Immunol. 2008;20:645-57.

261. Gao N, Jennings P, Guo Y, Yuan D. Regulatory role of natural killer (NK) cells on antibody responses to Brucella abortus. Innate Immun. 2011;17:152-63.
262. Jennings $\mathrm{P}$, Yuan D. NK cell enhancement of antigen presentation by B lymphocytes. J Immunol. 2009;182:2879-87.

263. Whitmire JK, Slifka MK, Grewal IS, Flavell RA, Ahmed R. CD40 ligand-deficient mice generate a normal primary cytotoxic T-lymphocyte response but a defective humoral response to a viral infection. J Virol. 1996;70:8375-81.

264. McCausland MM, Yusuf I, Tran H, Ono N, Yanagi Y, Crotty S. SAP regulation of follicular helper CD4 T cell development and humoral immunity is independent of SLAM and Fyn kinase. J Immunol. 2007;178:817-28.

265. Crotty S, Kersh EN, Cannons J, Schwartzberg PL, Ahmed R. SAP is required for generating long-term humoral immunity. Nature. 2003;421:282-7.

266. Choi YS, Kageyama R, Eto D, Escobar TC, Johnston RJ, Monticelli L, Lao C, Crotty S. ICOS receptor instructs T follicular helper cell versus effector cell differentiation via induction of the transcriptional repressor Bcl6. Immunity. 2011;34:932-46.

267. Zhou G, Juang SW, Kane KP. NK cells exacerbate the pathology of influenza virus infection in mice. Eur J Immunol. 2013;43:929-38.

268. Sun H, Sun C, Xiao W. Expression regulation of co-inhibitory molecules on human natural killer cells in response to cytokine stimulations. Cytokine. 2013;10.1016/j.cyto.2013.09.016.

269. Kruse PH, Matta J, Ugolini S, Vivier E. Natural cytotoxicity receptors and their ligands. Immunol Cell Biol. 2014;92:221-9. 